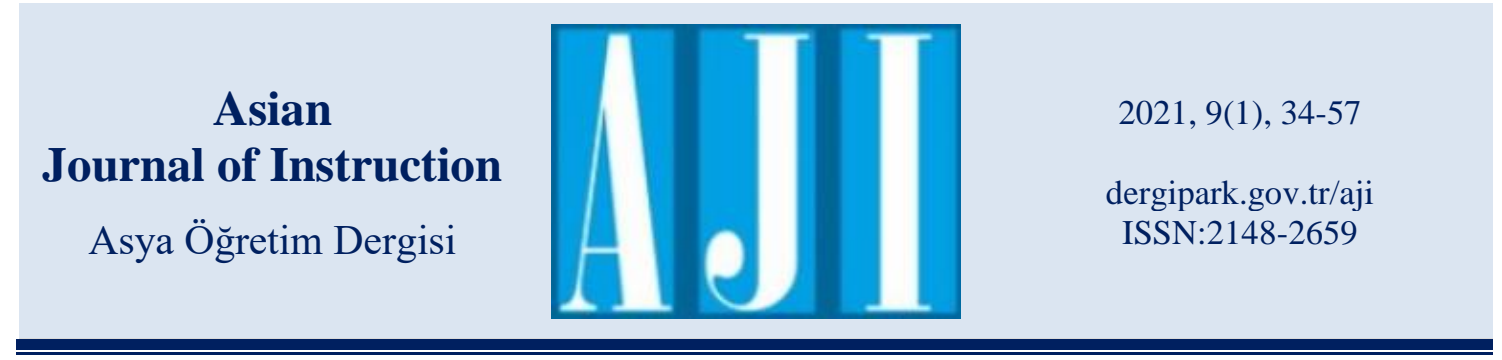

Kabul Tarihi: 25/04/2021

Yayınlanma Tarihi: 25/06/2021

\title{
Sınıf Öğretmeni Adaylarının Bilimsel Bilginin Doğasına Yönelik İnançlarının İncelenmesi*
}

\author{
Evrim Ural $^{1}$, Firuze Öztaş²
}

Ural, E., \& Öztaş, F. (2021). Sınıf öğretmeni adaylarının bilimsel bilginin doğasına yönelik inançlarının incelenmesi. Asya Öğretim Dergisi, 9(1), 34-57. https://doi.org/10.47215/aji.875217

Öz

Türkiye'de bilimin doğasına yönelik yürütülen çalışmaların ağırlıklı olarak fen bilimleri öğretmenleri ve öğretmen adayları ile gerçekleştirildiği görülmektedir. Buna karşın, çok az çalışma sınıf öğretmeni adaylarının bilimin doğasına yönelik inançlarına odaklanmaktadır. Bu araştırma, 1., 2. ve 3. sınıfta öğrenim gören sınıf öğretmeni adaylarının bilimsel bilginin doğasına yönelik algılarını, mevcut görüşlerinden yola çıkarak değerlendirmeyi ve görüşlerin sınıf düzeyine göre değişip değişmediğini belirlemeyi amaçlamaktadır. Durum çalışması olarak desenlenen bu araştırmada veriler, öğretmen adaylarından "Bilimin Doğası Hakkında Görüşler Anketi'nden (VNOS-C)" seçilen sorular aracılı̆̆ıyla toplanarak, betimsel analiz tekniğiyle çözümlenmiştir. Araştırmanın bulguları, öğretmen adaylarının, "bilimin kesin olmayan doğasına", "bilimin deneysel doğasına", "bilimin çıkarıma dayalı doğasına" yönelik "yetersiz" görüşlerinin, "kabul edilebilir" ve "bilgili" kategorilerine göre daha fazla olduğunu ortaya çıkarmıştır. Ayrıca öğretmen adaylarının bilimsel bilginin doğasına yönelik görüşlerinin sınıf düzeyine göre belirgin farklılıklar göstermediği sonucuna ulaşılmıştır. Araştırma, öğretmen adaylarının, bilimsel bilginin doğasına yönelik yanlıș bilgilerine ve kavram yanılgılarına dikkat çekmekte ve bilimin doğası öğretiminin nasıl gerçekleştirilmesi gerektiğine yönelik öneriler sunmaktadır.

Anahtar Kelimeler: Bilimsel bilginin doğası, sınıf öğretmeni adayları, fen eğitimi

\section{Investigation of Primary School Teacher Candidates' Beliefs on the Nature of Scientific Knowledge}

\begin{abstract}
The studies related to the nature of science in Turkey have mainly been conducted with science teachers and science teacher candidates. In contrast, few studies focus on primary school teacher candidates' beliefs about the nature of science. This study aimed to evaluate the freshmen, second grade, and third-grade primary school teacher candidates' beliefs about the nature of scientific knowledge based on their current views and determine whether their views change according to the grade level. In this study, which was designed as a case study, the data were collected from

\footnotetext{
*Bu çalışma, "Sınıf öğretmeni adaylarının bilimsel okur-yazarlık düzeyleri ve bilimin doğası hakkındaki görüşlerinin incelenmesi”" başlıklı yüksek lisans tezinden üretilmiştir.

${ }^{1}$ Doç. Dr., Kahramanmaraş Sütçü İmam Üniversitesi Matematik ve Fen Bilimleri Eğitimi, https://orcid.org/0000-0002-5427-2023, evrimural@gmail.com

2 Doktora Öğrencisi, Hacettepe Üniversitesi, Temel Eğitim Bölümü, https://orcid.org/0000-0001-5577-0983, firuze.oztas02@gmail.com
} 
pre-service teachers through the selected questions from "Views of Nature of Science (VNOS-C)" and analyzed using a descriptive analysis technique. The findings of the study revealed that the percentage of "naive" views of primary school teacher candidates about the "tentative nature of science", "empirical nature of science", and "inferential nature of science" were higher than the percentage of "has merit" and "informed" categories. Also, it was concluded that the views of primary school teacher candidates about the epistemology of scientific knowledge did not differ significantly according to the grade level. The research draws attention to the misinformation and misconceptions of primary school teacher candidates regarding the nature of scientific knowledge. It provides suggestions for effective education of the nature of science.

Keywords: The nature of scientific knowledge, primary school teacher candidates, science education

\section{Giriş}

Bilimsel gelişmeler ve teknolojik ilerlemelerin ön planda olduğu bilgi çağında, bilimi anlamak önemlidir. Bilimin sonuçlarının toplumsal yaşamımızı etkilemesi ve çağın ihtiyaç duyduğu insan modelinin yetiştirilmesi, bilim öğrenmenin entelektüel bir zorunluluk haline geldiğini göstermektedir (Yıldırım, 2014). Bilim ve teknolojideki hızlı ilerleme, mevcut bilgilerimizin bu ilerlemelere ayak uydurarak sürekli yenilenmesini zorunlu kılmıştır. Bilim alanındaki ilerlemeler, fen derslerine verilen önemin artmasını ve eğitim programlarının da bu hızlı değişime uyum sağlayacak şekilde planlanmasını sağlamıştır. Bu amaçla, eğitim programlarında değişikliklere gidilerek, çağın ihtiyaç duyduğu insan modelinin yetiştirilmesi hedeflenmiştir (Emren, 2018).

Fen eğitiminin amaçları arasında, sürekli gelişen bilgi çağına ayak uydurabilecek, güncel buluşlardan yararlanabilecek bireyler yetiştirmek ve teknolojik gelişmelerin her aşamasında bilimin gerekliliğinin anlaşılmasını sağlamak yer almaktadır (Hançer, Şensoy \& Yıldırım, 2003). Öğrencilerin bilimin doğasını keşfetmesi, fen-teknoloji-toplum-çevre ilişkisini kavrayabilmesi, bilimsel içerik bilgisini anlayabilmesi, fen dersine ilgisinin artması ve olumlu tutum geliştirebilmesi, yani fen okuryazarı birey olabilmesi için fen eğitimine ilişkin kavramları bilmeleri gerekmektedir (Kavak, Tufan \& Demirelli, 2006).

Abd-El-Khalick, Bell ve Lederman'a (1998) göre fen okuryazarı birey, bilimsel bilgi ve kavramları fen bilimleri bağlamında kullanarak mantıklı kararlar alabilen bireydir. Bilimin doğası ise, fen okuryazarlığının önemli boyutlarından birini oluşturmaktadır. Bilimin doğasını anlamak genel olarak; bilimsel sürecin doğasını anlamayı, bilimsel araştırma metotlarını bilmeyi ve bilimsel dünya görüşüne sahip olmayı gerektirir (AAAS, 1989). Bu bağlamda bilimin doğası, bilimin ne anlama geldiğini, hangi amaçla kullanıldığını, bilimsel bilginin oluşumunun süreç ve gerekçelerini, bilimsel bilginin zamanla değişebileceğini ve var olan bilgilerin yeni araştırmalarda nasıl kullanıldığını anlamayı kapsamaktadır (MEB, 2013).

Pozitivist anlayışa göre bilim, bilim insanları tarafindan belirlenen bilimsel süreç ve prensiplere bağlı olarak bilim insanlarınca üretilir. Bu bağlamda bilim, insan tarafindan oluşturulmuştur ve tam anlamıyla objektif değildir. Çünkü bilim, bilim insanları tarafindan keşfedilmemiş, oluşturulmuştur (Çakıcı, 2009). Yapılan araştırmalarda öğrencilerin ve öğretmenlerin bilimsel süreçte, bilim insanlarının bilimsel yöntemleri kullanarak bilimde kesin gerçekleri objektif bir şekilde ortaya çıkardıkları şeklinde düşünceye sahip oldukları görülmektedir (Hanuscin, Akerson \& Phillipson-Mower, 2006). Öğretmen adaylarının, öğrencilerin bilimin doğasına ilişkin anlayışlarını geliştirmeden önce kendilerinde var olan bilimsel bilgiyi fark etmeleri önemlidir. Ural'a (2016) göre, öğretmenlerin öğretim yöntemleri ve bilgi seviyeleri, öğrencilerin öğrenmelerini etkilemektedir.

Pozitivist anlayışa sahip öğretmenlere göre bilim, "objektif, evrensel, gözlem ve deneye dayalı, kesin gerçekleri ortaya çıkaran, olayları kanıtlayan, kendine özgü bir metodu olan, önyargıdan 
bağımsız olarak algılanır (Çakıcı, 2009). Pozitivist anlayıştan farklı olarak, çağdaş anlayışa göre bilimin özellikleri ise şu şekildedir (Çakııı, 2009):

$\checkmark$ Fiziksel dünyayı anlamada kullanılan bir insan çabasıdır.

$\checkmark$ Bilim, her zaman kesin olmayan bilgiyi üretir.

$\checkmark$ Bilimsel araştırmalarda birçok yöntemden yararlanılır. Bilim yapmak için evrensel olarak kabul edilmiş tek bir belirli işlem basamakları yoktur. Bu bilimsel yöntemler, bir dizi kuralları izlemezler.

$\checkmark$ Bilim tamamen gözlem ve deneye dayalı değildir. Bilimde çıkarımlar da önemlidir.

$\checkmark$ Bilimsel teoriler de kanunlar kadar önemlidir. Teoriler ile kanunlar arasında hiyerarşik bir yap1 yoktur.

$\checkmark$ Bir teori bilimsel olmak için kanıtla desteklenmek zorunda değildir.

Fen bilimleri öğretiminin en önemli amaçlarından birisi öğrencilerin bilimsel okuryazar bireyler olarak yetişmeleridir. Bilimsel okuryazar bireyler araştıran, sorgulayan ve herhangi bir bilgiyi sorgulamadan kabul etmeyen bireylerdir. Her türlü bilgi kaynağına neredeyse sınırsız bir ulaşım sağlanabilen günümüz koşullarında, bilgi kirliliği de en büyük sorunlardan bir tanesidir. $\mathrm{Bu}$ bağlamda, bireylerin bilimsel okuryazar olmaları bilimsel olanla bilimsel olmayanı ayırt etmelerini de sağlayacaktır. Bilimsel bilginin mutlak olmadığı ve değişebilir olduğu, fen bilimlerindeki dinamik yapının anlaşılması ve araştırma, sorgulama gibi becerilerin öneminin anlaşılması için oldukça önemlidir. Şüpheci olmak, bir bilgiyi destekleyen kanıtları incelemek ise bilimsel okuryazar bir birey olabilmek için geliştirilmesi gereken özelliklerdir. Bilimsel bir bilgi oluşturulurken deneyler ve gözlemlerin öneminin anlaşılması ise, bilimsel yöntemin anlaşılması için önem taşımaktadır. Bireylerin bilimsel bilgiyi öğrenebilmeleri için bilimsel bilginin özellikleri ve bilimsel bilginin nasıl elde edildiği konularında zihinlerinde doğru şemaların oluşması gerekmektedir. Ural'a (2016) göre, bu şemaların oluşturulmasında ise öğretmenlerin rolü oldukça önemlidir.

Çalışma kapsamında, sınıf öğretmeni adaylarının bilimsel bilginin doğası ile ilgili görüşleri incelenmiştir. Örneklem grubu olarak sınıf öğretmeni adaylarının seçilmesinin nedeni, bireylerin bilimle ilgili ilk fikirlerinin ilkokulda oluşmasıdır. İlkokulda 3. sınıftan itibaren fen dersleri görmeye başlayan öğrenciler, bilimsel bilgi ile ilk kez resmi olarak tanışmaktadırlar. Bu bağlamda, sınıf öğretmenlerinin fen bilimlerinin tanıtılmasında ve öğrencilerin zihinlerinde bilim ve bilimsel bilgi kavramları konusunda doğru şemaların oluşturulmasında oldukça büyük rolleri vardır. Öğretmen adaylarının, bilimsel bilginin ne olduğu, nasıl oluşturulduğu ile ilgili düşünceleri, kullandıkları öğretim yöntemlerini ve fen derslerine bakışlarını da etkileyecektir. $\mathrm{Bu}$ nedenle, sınıf öğretmenleri adaylarının konu ile ilgili görüşlerinin incelenmesi, kendi sınıflarında fen derslerindeki yaklaşımlarını belirlemek ve lisans öğrenimleri boyunca konu ile ilgili bilgilerinin gelişimlerini incelemek ve olası çözüm önerilerini tartışmak için katk1 sağlayacaktır. Sınıf öğretmeni adaylarının bilimsel bilginin doğası hakkındaki görüşleri, bilimsel bilgiyi öğretirken ve öğrencilerin bilimsel süreç becerilerinin gelişimi için çeşitli etkinlikleri tasarlarken yapacakları sinıf aktivitelerini etkileyecektir (Ural, 2016).

$\mathrm{Bu}$ çalışma sınıf öğretmeni adaylarının, "bilimsel bilginin doğasına" yönelik görüşlerinin incelenmesini ve adayların görüşlerinin sınıf düzeyine göre farklılık gösterip göstermediğini belirlemeyi amaçlamaktadır. Bu amaca yönelik olarak, şu sorulara cevap aranmıştır:

1. Sınıf öğretmeni adaylarının, "bilimin kesin olmayan doğasına" ilişkin görüşleri sınıf düzeyine göre değişim göstermekte midir?

2. Sınıf öğretmeni adaylarının, "bilimin deneysel doğasına" ilişkin görüşleri sınıf düzeyine göre değişim göstermekte midir? 
Sınıf Öğretmeni Adaylarının Bilimsel Bilginin Epistemolojisine Yönelik İnançlarının İncelenmesi

3. Sınıf öğretmeni adaylarının, "bilimin çıkarıma dayalı doğasına" ilişkin görüşleri sınıf düzeyine göre değişim göstermekte midir?

\section{Yöntem}

\subsection{Araştırma Modeli}

Bu çalışmada, araştırmanın doğasına uygun olduğu düşünülen, nitel araştırma yöntemlerinden durum çalışması deseni kullanılmıştır. Durum çalışmalarında amaç, bir olaya ilişkin ayrıntıları görmek, olası açıklamaları geliştirmek ve değerlendirmektir (Gall, Borg \& Gall, 1996). Durum çalışmasındaki en belirleyici özellik, bir ya da birkaç durumun derinlemesine araştırılmasıdır (Yıldırım \& Şimşek, 2008). Bu araştırmada, sınıf öğretmeni adaylarının bilimsel bilginin doğasına yönelik algılarını, mevcut görüşlerinden yola çıkarak değerlendirmek ve konuyla ilgili yanlış kavramalarına ilişkin ayrıntıları görmek amaçlandığı için durum deseni tercih edilmiştir.

\section{2. Çalıșma Grubu}

Araştırmanın çalışma grubunu, 2017-2018 eğitim ve öğretim yılında bir devlet üniversitesinde, 1., 2. ve 3. sınıfta öğrenim görmekte olan, toplam 119 sinıf öğretmeni adayı oluşturmaktadır. Araştırma kapsamında yer alan çalışma grubuna, seçkisiz olmayan örnekleme yöntemlerinden "uygun örnekleme" ile ulaşılmıştır. Uygun örnekleme yöntemi, zaman, para ve işgücü kaybını önlemeyi amaçlayarak, araştırmacının kolayca ulaşabileceği bir örneklemden verileri toplanması olarak tanımlanabilir (Büyüköztürk, Kılıç Çakmak, Akgün, Karadeniz \& Demirel, 2018).

\subsection{Veri Toplama Aracı}

Araştırma kapsamında ihtiyaç duyulan veriler, Lederman, Abd-El-Khalick, Bell ve Schwartz (2002) tarafından geliştirilen, Bilimin Doğası Hakkındaki Görüşler Anketi'nde (VNOS-C) yer alan bilimsel bilginin doğasına yönelik soruların katılımcılara yöneltilmesiyle toplanmıştır. VNOS-C anketi, Lederman ve diğerleri (2002) tarafından geliştirilmiş olup, anketin Türkçesi, Küçük'ün (2006) çalışmasından alınmıştır. VNOS-C anketi birçok çalışmada, ilkokul öğretmen adaylarına (Abd-El-Khalick, 2001), orta öğretim öğretmen adaylarına ve öğretmenlere (Abd-ElKhalick \& Lederman, 2000; Lederman vd., 2002) uygulanmış ve katılımcıların konu ile ilgili görüşlerinin belirgin bir şekilde ortaya çıkarıldığı belirlenmiştir. Değinilen anket, bilimin doğasının yedi alt boyutunu temsil eden 10 adet açık uçlu sorudan oluşmaktadır. Çalışmanın amacı doğrultusunda, bilimsel bilginin doğasına yönelik olarak, "bilimin kesin olmayan doğası", "bilimin deneysel doğası" ve "bilimin çıkarıma dayalı doğası" alt boyutlarında yer alan 1., 2., 3., 4., 5., 6. ve 7. sorular kullanılmıştır. Çalışma kapsamında ele alınan sorular ile ölçülmek istenen özellikler Tablo 1'de verilmektedir:

Tablo 1. Bilimsel Bilginin Doğası ile İlgili Çalışma Kapsamında Kullanılan Sorular ve Ölçülmek İstenilen Özellikler (Küçük, 2006)

\section{Anket Soruları}

\section{Ölçülmek İstenilen Özellikler}

1) Size göre fen bilimi nedir? Fen bilimini Öğretmen adaylarının, sahip oldukları bilimsel bilgi (fizik, kimya, biyoloji, vb.) diğer alanlardan hakkındaki düşüncelerini ve özellikle bilimin (felsefe, din, vb.) farklı kılan özellik ya da deneysel ve değişebilir doğasıyla ilgili özellikler nelerdir?

2) Sizce deney nedir? düşüncelerini ortaya çıkarmayı amaçlamaktadır.

Öğretmen adaylarının deneyi hangi amaç için kullandıklarını ve deneyin doğasına yönelik sahip oldukları bilgileri ortaya çıkarmayı amaçlamaktadir. 
Tablo 1. (devami)

\begin{tabular}{|c|c|}
\hline Anket Soruları & Ölçülmek İstenilen Özellikler \\
\hline $\begin{array}{l}\text { 3) Bilimsel bilginin gelişimi deney yapmayı } \\
\text { gerektirir mi? }\end{array}$ & 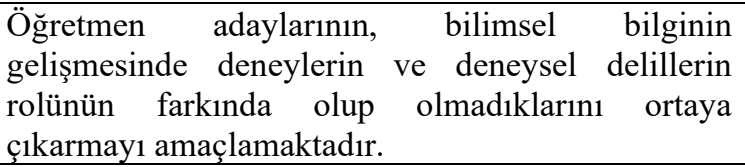 \\
\hline $\begin{array}{l}\text { 4) Fen ders kitapları çoğunlukla atomu, } \\
\text { merkezinde artı yüklü protonlar ve yüksüz } \\
\text { nötronlardan oluşan bir çekirdek ve bu çekirdek } \\
\text { etrafında dönen eksi yüklü elektronlardan } \\
\text { oluşan bir yapı olarak gösterirler. } \\
\text { - Bilim adamları atomun yapısı hakkında } \\
\text { nasıl bu kadar emindirler? } \\
\text { - Atomun nasıl bir yapıda olduğunu } \\
\text { belirlemek için bilim adamlarının nasıl } \\
\text { kanıtlar kullandıklarını düşünüyorsunuz? }\end{array}$ & $\begin{array}{l}\text { Öğretmen adaylarının, bilimde insan çıkarımının, } \\
\text { yaratıcılığının ve modellerin rolü ile bilimsel } \\
\text { modellerin gerçeğin kopyaları olmadığını anlayıp } \\
\text { anlamadıklarını ortaya çıkarmayı amaçlamaktadır. }\end{array}$ \\
\hline $\begin{array}{l}\text { 5) Bir bilimsel teori ile bilimsel kanun arasında } \\
\text { bir fark var mıdır? Düşüncenizi bir örnek } \\
\text { vererek açıklayınız. }\end{array}$ & $\begin{array}{l}\text { Öğretmen adaylarının, bilimin ürünleri arasındaki } \\
\text { ilişkilerle ilgili kavram yanılgılarına sahip olup } \\
\text { olmadıklarını ortaya çıkarmayı amaçlamaktadır. } \\
\text { Birçok öğrenci, teori ve yasa arasında hiyerarşik bir } \\
\text { ilişki olduğunu düşünmekte ve onlara göre yeterli } \\
\text { delil toplanırsa teoriler yasaya dönüşür. }\end{array}$ \\
\hline $\begin{array}{l}\text { 6) Bilim adamları bir teoriyi (atomik teori, } \\
\text { kinetik moleküler teori, evrim teorisi gibi) } \\
\text { geliştirdikten sonra, bu teori zamanla hiç değişir } \\
\text { mi? }\end{array}$ & $\begin{array}{l}\text { Öğretmen adaylarının, bilimsel iddiaların kesin } \\
\text { olmayan doğası ve bu iddiaların niçin değiştiği } \\
\text { hakkındaki fikirlerini ortaya çıarmayı } \\
\text { amaçlamaktadır. }\end{array}$ \\
\hline $\begin{array}{l}\text { 7) Fen kitapları, türü benzer özelliklere sahip ve } \\
\text { çiftleştiklerinde verimli döller oluşturabilen bir } \\
\text { grup organizma olarak tanımlar. Bilim adamları } \\
\text { türün özelliklerinin ne olduğuna dair nasıl emin } \\
\text { olabiliyorlar? Bilim adamlarının 'tür nedir?'" } \\
\text { sorusuna cevap vermek için hangi kanıtlar } \\
\text { kullandıklarını düşünüyorsunuz? }\end{array}$ & $\begin{array}{l}\text { Öğretmen adaylarının, bilimde insan yaratıcılığının } \\
\text { ve hayâl gücünün rolü ile bu faktörlerin çalışmanın } \\
\text { hangi aşamada belirdiğiyle ilgili ve özellikle } \\
\text { bilimin deneysel doğasıyla ilgili düşüncelerinin } \\
\text { ortaya çıkmasını amaçlamaktadır. }\end{array}$ \\
\hline
\end{tabular}

Kullanılan soruların bilimin doğasının alt boyutlarına göre dağılımı Tablo 2'de verilmektedir.

Tablo 2. VNOS- C Anket Sorularının Bilimin Doğasının Alt Boyutlarına Göre Dağılımı

\begin{tabular}{ll}
\hline Bilimin Doğasının Alt Boyutları & VNOS-C Anketindeki Açık Uçlu Sorular \\
\hline Bilimin Kesin Olmayan Doğası & 1., 5. ve 6. Soru \\
\hline Bilimin Deneysel Doğası & 2. ve 3. Soru \\
\hline Bilimin Çıkarıma Dayalı Doğası & 4. ve 7. Soru \\
\hline
\end{tabular}

\subsection{Veri Toplama Süreci}

Veri toplama aşamasında, katılımcıların gönüllülüğü esas alınmıştır. VNOS-C anketi, araştırmacı tarafından 1., 2. ve 3. sınıf öğretmen adaylarına yazılı bir form şeklinde dağıtılmış ve açık uçlu soruları yanıtlamaları istenmiştir. Verilerin toplanması sırasında katılımcıların, anket sorularındaki doğru-yanlış cevaplara ilişkin herhangi bir endişe durumu taşımamaları gerektiği belirtilmiştir.

\subsection{Verilerin Analizi}


Bu araştırmada, VNOS-C anketinden elde edilen veriler, Doğan ve Abd-El-Khalick'in (2008) çalışmasında kullandıkları, "yetersiz", "kabul edilebilir" ve "bilgili”" şeklindeki üç ölçüte göre kategorize edilmiştir. Öğretmen adaylarının bilimin doğasına uygun olmayan, zayıf bakış açısına sahip cevapları "yetersiz", bilimin doğasını yansıtan fakat tam anlamıyla açıklayamadıkları makul cevapları "kabul edilebilir" ve bilimin doğasına ilişkin örneklerle pekiştirdikleri yeterli cevapları ise "bilgili" olarak betimlenmiştir. Katılımcılardan toplanan veriler, birinci sınıf öğretmen adayları için (A1-A40); ikinci sınıf öğretmen adayları için (B1B39); üçüncü sınıf öğretmen adayları için (C1-C40) şeklinde numaralandırılmıştır. Öğretmen adaylarının, ankette yer alan her bir soruya ilişkin verdikleri cevaplar, bir bütün olarak değerlendirilmiş ve literatürde yer alan çalışmaların (Çavuş, 2010; Özcan, 2013) cevap anahtarlarından yararlanılarak analiz edilmiştir. Her bir soruya verilen cevaplar değinilen şekilde kategorize edilerek, frekans analizi yapılmış ve şekiller oluşturulmuştur. Her bir soruya ait şekilde, katılımcıların her bir kategorideki cevap yüzdeleri ve sınıf düzeylerine yer verilmiştir.

\subsection{Etik Kurul İzin}

Yapılan bu çalışmada "Yükseköğretim Kurumları Bilimsel Araştırma ve Yayın Etiği Yönergesi” kapsamında uyulması belirtilen tüm kurallara uyulmuştur. Bu çalışma için etik kurul izni Kahramanmaraş Sütçü İmam Üniversitesi Fen Bilimleri Araştırmaları Etik Kurulu'nun 17.04.2018 tarihli ve 2018/08 sayılı toplantıda alınan kararı ile alınmıştır.

\section{Bulgular}

$\mathrm{Bu}$ bölümde, verilerin analizi sonucu elde edilen bulgular yer almaktadır. Her bir soruya verilen cevaplar, veri analizi kısmında açıklandığı şekilde kategorize edilmiştir.

\subsection{Bilimin Kesin Olmayan Doğası Alt Boyutuna Yönelik Bulgular}

VNOS-C anketinin birinci sorusu, "Size göre fen bilimi nedir? Fen bilimini (fizik, kimya, biyoloji, vb.) diğer alanlardan (felsefe, din, vb.) farkl kllan özellik ya da özellikler nelerdir?” şeklindedir. Sınıf öğretmeni adaylarının, bu soruya yönelik görüşleri kategorilere ayrılmış ve sınıf düzeyine göre yüzdelik dağılımlarına Şekil 1'de yer verilmiştir:

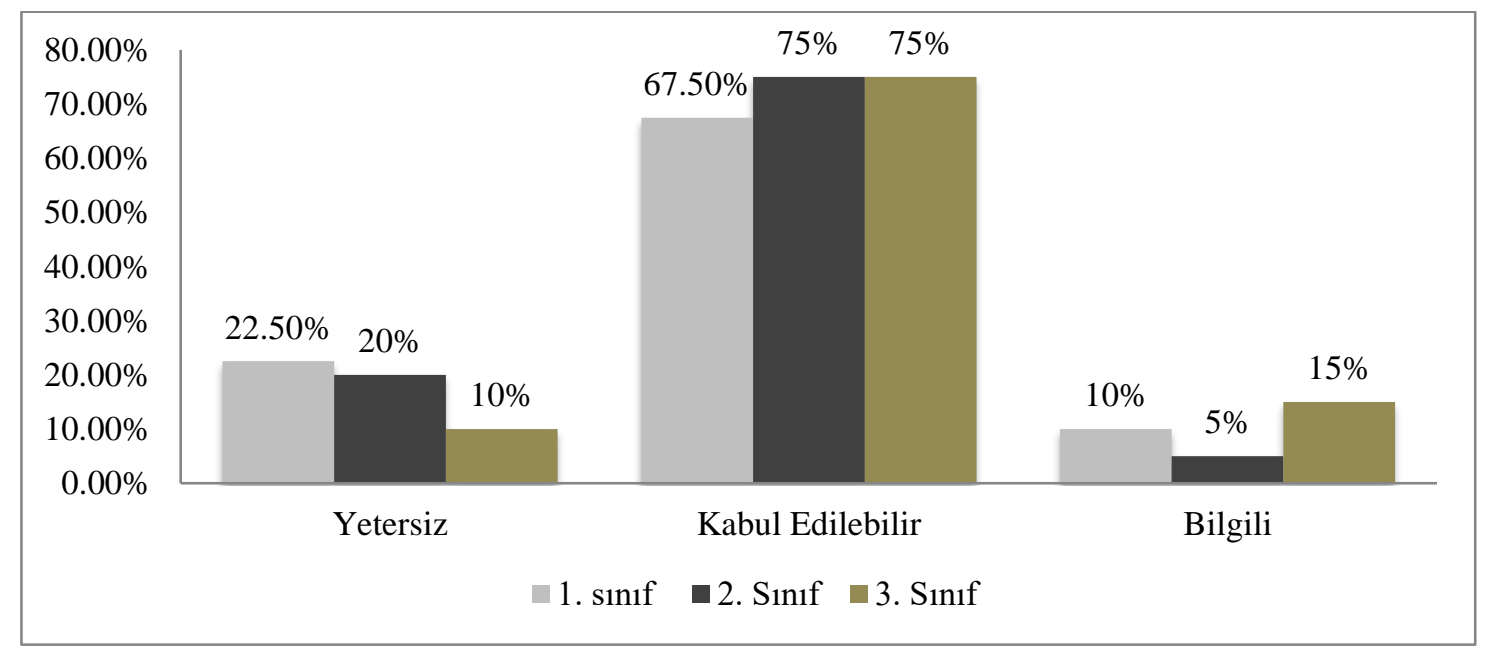

Şekil 1. Öğretmen Adaylarının VNOS-C'nin Birinci Sorusuna Verdikleri Cevapların Sınıf Düzeylerine Göre Yüzdelik Dağılımları 
Şekil 1 incelendiğinde, 1. sınıf öğretmen adaylarının $(\% 22,5)$, diğer sınıflara göre daha fazla "yetersiz" görüşe sahip oldukları görülmektedir. "Yetersiz" görüşlerin oranı, 1. sınıf $(\% 22,5)$ ve 2. sinıflarda $(\% 20)$ benzerlik göstermektedir ancak 3. sinıflarda $(\% 10)$ bu oranın belirgin bir azalış gösterdiği belirlenmiştir. "Kabul edilebilir" görüşlerin sınıf düzeyine göre oranları incelendiğinde belirgin farklılıklar görülmemektedir. Ayrıca öğretmen adaylarının, ilgili soruya yönelik en fazla "kabul edilebilir" düzeyde görüş bildirdikleri belirlenmiştir. "Bilgili" kategorisindeki görüşlerin, 3. sınıf öğretmen adaylarında (\%15) daha fazla olduğu görülmektedir. 2. sınıf öğretmen adayları ise (\%5) en az "bilgili" düzeyde görüş bildiren sınıf olmuştur.

\section{“Yetersiz” Kategorisine Ait Görüşler}

Yetersiz görüşlere sahip öğretmen adaylarının, fen bilimini tanımlarken, kesin olduğuna ve herkes tarafindan kabul edildiğine yönelik yanlış bilgilere sahip oldukları görülmüştür.

“Gerçek doğru varsa ve kanıtlanmışsa, yoruma kapalıdır.” (A22-Yetersiz).

"Fen bilimlerinde kesin bir sonuç varken, felsefe gibi alanlarda kesin sonuç yoktur." (B29Yetersiz).

"Fen bilimleri, deney ve gözlemlerle kesin sonuçlar elde edilebilen bilimleri kapsar. Fen bilimlerinden elde edilen sonuçlar, sosyal bilimlerde olduğu gibi kişiden kişiye değişmez, yorum götürmez ve evrenseldir"'(C1-Yetersiz).

\section{“Kabul Edilebilir" Kategorisine Ait Görüşler}

Kabul edilebilir görüşlere sahip öğretmen adaylarının, deney ve gözlemin öneminden bahsettikleri ancak delillerin önemine değinmedikleri görülmektedir. Fen biliminin tanımına yönelik görüşler, her üç sınıf düzeyinde de benzerlik göstermektedir.

"Doğadaki olaylarl, varlıkları deneylerle ve gözlemlerle açılklayan bilimdir" (A7-Kabul edilebilir).

"Maddelerin yapısını, şeklini, hareketini gözlem ve deneye dayanarak inceleyen bilim dalıdır" (B4-Kabul edilebilir).

"Fen bilimi, gözlem ve deneye dayanan çalışmalarla elde edilen bilgilerdir. Deneme-yanılmaya dayalı olması farklı kllan özelliklerden biridir" (C15-Kabul edilebilir).

Bazı öğretmen adayları, fen bilimlerinde deney ve gözlemlerin önemine değinmiş ancak fen bilimlerinin tanımına ve fen bilimlerini diğer alanlardan ayıran özelliklere yönelik yanlış bilgilerinin, bu kategoride de devam ettiği görülmüştür.

"Fen bilimi gözlem ve deneyin yapıldiğg çalışmalarla elde edilen sistemli ve birikimli çalışmaların bütünüdür. Diğer bilimlerden farkl kılan, gözlem ve deneylerle kontrol etmeye imkân sağlamasıdır. İleri sürülen varsayımların kanıtlanabilmesi her defasında aynı sonuçlara ulaşabilmesi, herkes tarafindan kabul görmesidir. Öznel değil daha çok nesnel olmasıdır" (C14-Kabul edilebilir). 


\section{“Bilgili”" Kategorisine Ait Görüşler}

Bilgili görüşlere sahip öğretmen adaylarının, fen bilimlerini doğru bir şekilde tanımladıkları ayrıca fen bilimini diğer alanlardan ayıran özellikler için deney-gözlemlerin olması ve delillere dayalı olması gerektiği yönünde görüş bildirdikleri görülmüştür.

"Fen bilimleri insanların doğayla olan ilişkisidir. İnanların maddesel çevresini denetlemek ve değiştirmek amacıyla geliştirdiği teknolojik bilgileri kapsayan bilimdir. Diğer alanlardan farklı kılan özellikleri; deney yapılması, gözleme ve keşfe önem vermesi, delillere dayalı olmasıdır" (C20-Bilgili).

Bilimin kesin olmayan doğası alt boyutunda yer alan VNOS-C anketinin beşinci sorusu, "Bir bilimsel teori ile bilimsel kanun arasında bir fark var mıdır? Düşüncenizi bir örnek vererek açıklayınız." şeklindedir. Sınıf öğretmeni adaylarının, bu soruya yönelik görüşleri kategorilere ayrılmış ve sınıf düzeyine göre yüzdelik dağılımlarına Şekil 2'de yer verilmiştir:

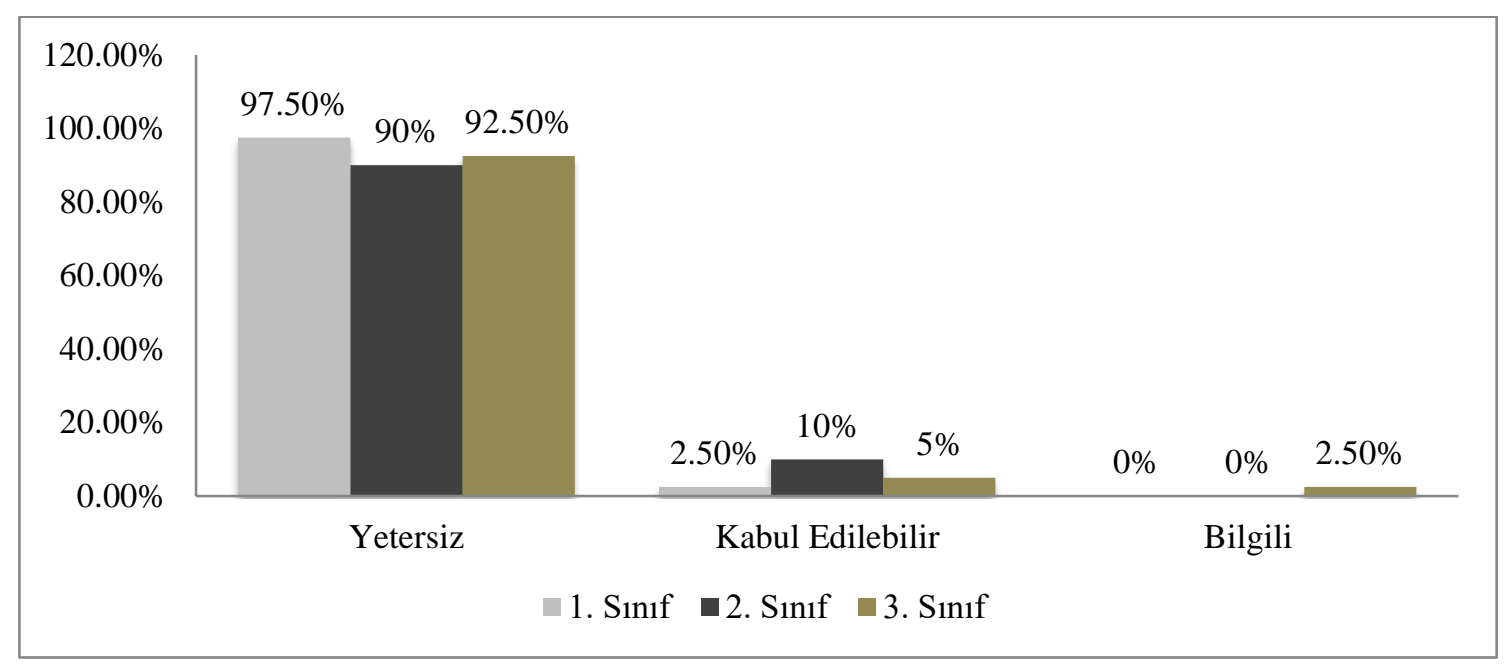

Şekil 2. Öğretmen Adaylarının VNOS-C'nin Beşinci Sorusuna Verdikleri Cevapların Sınıf Düzeylerine Göre Yüzdelik Dağılımları

Şekil 2 incelendiğinde, 1. sınıf öğretmen adaylarının (\%97,5), diğer sınıflara göre daha fazla "yetersiz" görüşe sahip oldukları görülmektedir. "Yetersiz" görüşlerin oranı, 2. sinıf (\%90) ve 3. sinıflarda $(\% 92,5)$ benzerlik göstermektedir. Ayrıca öğretmen adaylarının, ilgili soruya yönelik en fazla "yetersiz" düzeyde görüş bildirdikleri belirlenmiştir. "Kabul edilebilir" kategorisi sinıf düzeyine göre incelendiğinde, 2. sınıf öğretmen adaylarının (\%10) görüşlerinin oranının, diğer sınıflara göre daha fazla olduğu belirlenmiştir. Kabul edilebilir görüşlerin oranı, 1. sınıflarda $(\% 2,5), 2$. sinıflarda $(\% 10)$ ve 3. sinıflarda (\%5) şeklindedir. Yalnızca 3. sinıf öğretmen adayların $(\% 2,5)$ "bilgili” düzeyde görüş bildirdikleri görülmüştür.

\section{“Yetersiz” Kategorisine Ait Görüsşler}

Bilimsel teori ve kanunlara ilişkin yetersiz görüşler, her üç sınıf düzeyinde de benzerlik göstermektedir. 1., 2. ve 3. sınıf öğretmen adaylarının, teorilerin kanıtlanmamış, kanunların ise kanıtlanmış olduğu ayrıca teorilerin kesinleşince bilimsel kanuna dönüşeceği yönünde yanlış bilgilere sahip olduğu belirlenmiştir.

"Teori ispatlanırsa kanun olur" (A22-Yetersiz). 
"Teori değişebilir, kanun değişmeyen bilgilerdir. Bilimsel teoriyle yeni ilaçlar bulunabilir. Bilimsel kanun deney yapmaya gerek olmayan bilgilerdir" (B33-Yetersiz).

"Evet vardır. Teorinin kanıtlanması sonucunda herkesin uyması zorunu değildir. Fakat kanun olunca herkes uymak zorunda" (C34-Yetersiz).

1. sınıf öğretmen adaylarından bazıları, hipotez, teori ve bilimsel kanun arasında hiyerarşik bir yapı olduğuna yönelik görüş bildirmiştir.

"Teori, kanun kadar kesin olmamakla birlikte hipotezin doğrulanmış halidir. Kanun ise, teorinin kesinleşmiş halidir" (A12-Yetersiz).

\section{“Kabul Edilebilir” Kategorisine Ait Görüşler}

Öğretmen adaylarını kabul edilebilir kategorisindeki görüşleri incelendiğinde, bilimsel teori ve kanunlar arasında herhangi bir hiyerarşik yapı olmadığını belirtmelerine karşın yeterli açıklamalarda bulunmadıkları görülmüştür.

"Bilimsel teori ve bilimsel kanunun farklı şeyler olduğunu biliyorum” (A34-Kabul edilebilir).

"Fark yoktur. İkisi de deneyler ve araştırmalar sonucu ortaya çıkmıştır" (B8-Kabul edilebilir).

"Teori çürütülebilir, yanlışlanabilir. Bilimsel kanun hakkında bilgim yok" (C25-Kabul edilebilir).

Bilimin kesin olmayan doğası alt boyutunda yer alan VNOS-C anketinin altıncı sorusu, "Bilim adamları bir teoriyi (atomik teori, kinetik moleküler teori, evrim teorisi gibi) geliştirdikten sonra, bu teori zamanla hiç değişir mi?" şeklindedir. Sınıf öğretmeni adaylarının, bu soruya yönelik görüşlerinin sınıf düzeyine göre yüzdelik dağılımlarına Şekil 3 'te yer verilmiştir:

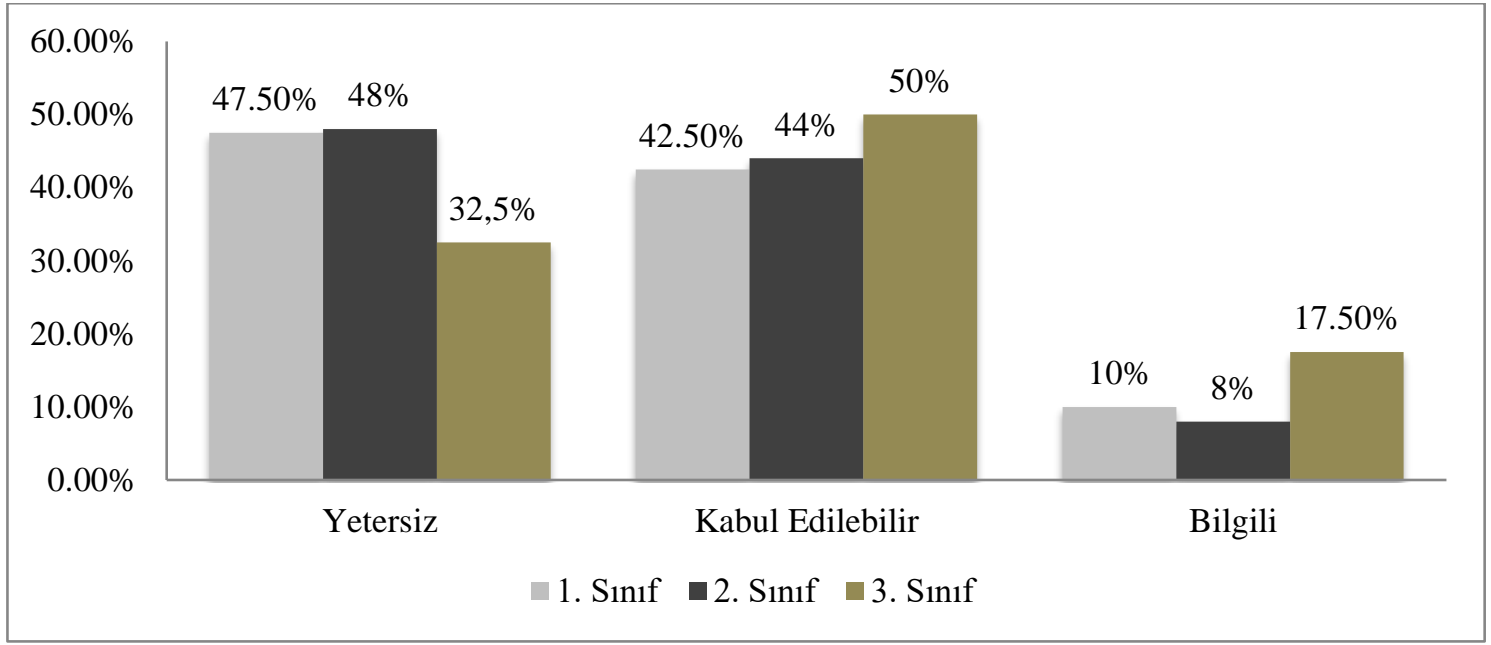

Şekil 3. Öğretmen Adaylarının VNOS-C'nin Altıncı Sorusuna Verdikleri Cevapların Sınıf Düzeyine Göre Yüzdelik Dağılımları

Şekil 3 incelendiğinde, öğretmen adaylarının bu soruya ilişkin görüşlerinin çoğunlukla "yetersiz" ve "kabul edilebilir" düzeyde olduğu görülmektedir. Yetersiz görüşlerin oran1, 1. sınıflar için $(\% 47,5), 2$. sınıflar için $(\% 48), 3$. sınıflar için $(\% 32,5)$ şeklindedir. 3. sınıf öğretmen 
Sınıf Öğretmeni Adaylarının Bilimsel Bilginin Epistemolojisine Yönelik İnançlarının İncelenmesi

adaylarının, diğer sınıflara oranla daha az yetersiz görüş bildirdikleri görülmüştür. En fazla "kabul edilebilir" görüşlerin 3. sınıf öğretmen adaylarına ait olduğu bulunmuştur. 1. ve 2. sınıf öğretmen adaylarının kabul edilebilir görüşlerinin oranı benzerlik göstermektedir. "Bilgili" kategorisindeki görüşlerin, 3. sınıf öğretmen adaylarında $(\% 17,5)$ daha fazla olduğu görülmektedir. 2. sınıf öğretmen adayları ise (\%8) en az "bilgili" düzeyde görüş bildiren sınıf olmuştur.

\section{“Yetersiz” Kategorisine Ait Görüsşler}

Öğretmen adaylarının, teorilerin zamanla değişip değişmeyeceğine yönelik görüşleri incelendiğinde, çoğunun değiş̧ebileceği yönünde görüş bildirdiği belirlenmiştir. Ancak öğretmen adaylarının, bilimsel teori ve kanunlara ilişkin yanlış bilgilerinin bu soruda da devam ettiği görülmüştür. Her üç sınıf düzeyindeki öğretmen adaylarından bazıları, teorilerin kanıt yetersizliğinden dolayı ispatlanamadığını savunmuştur. Bazı öğretmen adaylarının ise, bilimsel teorilere ilişkin örnekler veremedikleri belirlenmiştir.

"Bilimsel teori değişir. Çünkü bu kanttlanmamış bir düşüncedir. Kanttlayan veya daha iyisini bulan çıkarsa değişebilir” (A40-Yetersiz).

"Bilimsel teoriler gelişmezse kanunlaşamaz. Kanunlaşmazsa tamamen yok olacaktır" (B27Yetersiz).

"Teori, hipotez yeni bulgularla desteklendiği zaman ortaya çıkar. O yüzden değişebilir" (C11Yetersiz).

2. sınıf öğretmen adaylarından bazıları, teorilerin değişmeyeceğini savunmuştur.

“Bilimsel teori değişmez. Zaten yıllarca tartışılmış ve kanıtlanmıştır” (B26-Yetersiz).

3. sınıf öğretmen adaylarından bazıları ise, teorilerin kesinleşmediği için değişebileceğini savundukları görülmüştür.

"Bilimsel teoriler değişir. Çünkü teorilerin kesin doğruluğu ya da kesin yanlışlığı belirlenmemiştir. Bu teori üzerinde çalışarak doğruluğunu kanttlarız" (C9-Yetersiz).

\section{“Kabul Edilebilir” Kategorisine Ait Görüşler}

Öğretmen adaylarının, bilimsel teorilerin yeni bilgi ve bulgulara göre değişebileceği yönünde görüş bildirdikleri görülmektedir. Ancak bu görüşlerini, örneklerle destelemedikleri ya da yanlış örnekler verdikleri belirlenmiştir.

"Bilimsel teoriler değişebilir. Teknoloji ilerledikçe imkânlar artıyor ve ayrıntılı araştırmalar sonucunda yeni bulgulara rastlaniyor" (A21-Kabul edilebilir).

"Bilimsel teoriler zamanla değişebilir. İlk zamanlarda bilim insanlar dünyanın düz olduğunu savunurken, zaman ilerledikçe bu bilgi değişmiş ve dünyanın düz olmadığı bulunmuştur" (B33Kabul edilebilir).

"Teoriler değişebilir. Çünkü yeni sonuçlar ortaya çıkar ve araştırmaları farklı bakış açılarıyla da yeniden yaparlar" (C35-Kabul edilebilir). 


\section{“Bilgili”" Kategorisine Ait Görüşler}

Bilgili görüşlere sahip öğretmen adayları, bilimsel teorilerin yeni bilgilerle değişebileceğini ifade ederek, bu düşüncelerini örneklerle desteklemişlerdir.

"Bilimsel teoriler değisstirilebilir ve yerini yenileri alır. Örneğin; evrim teorisi, yalnızca bir teoridir. Bu teoriyi savunan insanlar da vardır, savunmayanlar da vardır” (A27-Bilgili).

"Değişir. Çünkü çeşitli deney ve bulgular sonucunda başka sonuçlara ulaşıp, önceki teoriler çürütülebilir. Atom teorileri sürekli değişmiştir” (B2-Bilgili).

"Teori zamanla değişir. Teoriler akl yürütülerek ve deneylerle çürütülebilir. Bilimde her zaman doğru bilgi yoktur. Her yeni bilgi eski teoriyi çürütebilir. Filojiston teorisi buna örnek olarak verilebilir" (C10-Bilgili).

\subsection{Bilimin Deneysel Doğası Alt Boyutuna Yönelik Bulgular}

VNOS-C anketinin ikinci sorusu, "Sizce deney nedir?" şeklindedir. Sınıf öğretmeni adaylarının, bu soruya yönelik görüşleri kategorilere ayrılmış ve sınıf düzeyine göre yüzdelik dağılımlarına Şekil 4'te yer verilmiştir:

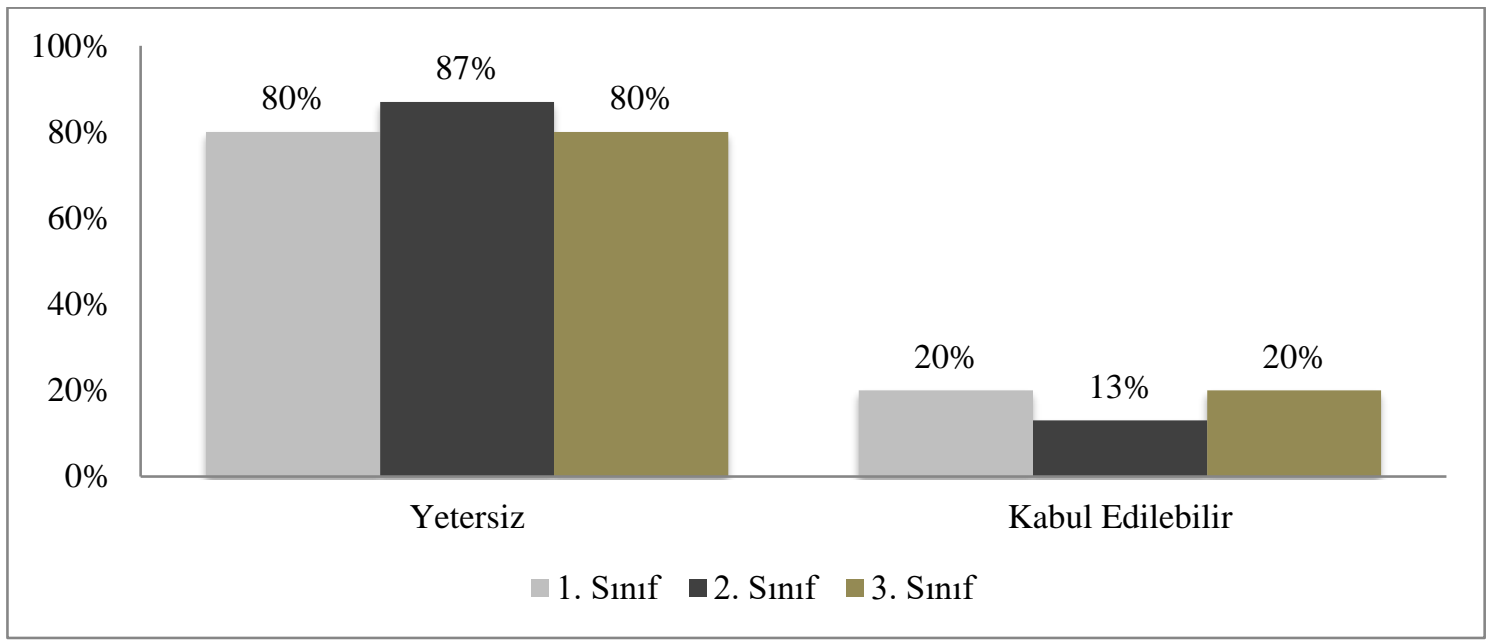

Şekil 4. Öğretmen Adaylarının VNOS-C'nin İkinci Sorusuna Verdikleri Cevapların Sınıf Düzeyine Göre Yüzdelik Dağılımları

Şekil 4 incelendiğginde, öğretmen adaylarının en fazla "yetersiz" düzeyde görüş bildirdikleri görülmektedir. "Bilgili" kategorisine ait görüş bulunmamaktadır. Yetersiz kategorisine bakıldığında, 1. sınıf $(\% 80)$ ve 3. sınıf (\%80) öğretmen adaylarının görüşlerinin oranlarının aynı olduğu görülmektedir. 2. sınıf öğretmen adaylarının (\%87) diğer sınıflara oranla daha fazla yetersiz düzeyde görüş bildirdiği belirlenmiştir. "Kabul edilebilir" kategorisindeki görüşlerin, 1. sınıf $(\% 20)$ ve 3. sınıf (\%20) düzeylerinde aynı olduğu görülmektedir. 2. sınıf öğretmen adaylarının (\%13) diğer sınıflara oranla daha az kabul edilebilir düzeyde görüş bildirdiği belirlenmiştir. 


\section{“Yetersiz" Kategorisine Ait Görüşler}

Öğretmen adaylarının deneyin tanımına ilişkin görüşleri incelenmiş ve her üç sınıfın da "yetersiz" cevaplarının benzerlik gösterdiği belirlenmiştir.Yetersiz görüşlere sahip öğretmen adaylarının, deneylerin laboratuvar ortamlarında, bir şeyi/hipotezi doğrulamak, somutlaştırmak ve kanıtlamak için yapılan işlemler bütünü olarak tanımladıkları belirlenmiştir.

"Deney, laboratuvar ortamında yapılan ispatlama işlemidir" (A20-Yetersiz).

"Bir hipotezin doğruluğunu ve yanlışlığını test etmek için başvurulan yöntemdir" (B35Yetersiz).

"Deney, bir olayı kanıtlamak ve ispatlamak için gerekli olan işlemlerle yapılan bir etkinliktir" (C13-Yetersiz).

\section{“Kabul Edilebilir” Kategorisine Ait Görüşler}

Kabul edilebilir görüşlere sahip öğretmen adaylarının, deneylerin hipotezlerin geçerliliğini artıran ya da onları ortadan kaldıran bir işlem olarak tanımladıkları görülmüştür. Ayrıca bazı öğretmen adayları deneylerin, hipotezi/teoriyi/kanunu destekleyen ya da yanlışlayan test edilebilir bir işlem olduklarını belirtmişlerdir.

"Bir hipotezin doğruluğınu ya da yanlışlı̆̆ını bulmak için yapılması gereken bir işlemdir" (A33-Kabul edilebilir).

"Sunulan hipotezlerin denenmesi ve bir sonuca varılması işlemidir" (B7-Kabul edilebilir).

"Deney, tahmin edilen durumların doğruluğunu ve yanlışlı̆̆ını kontrol etmek için yapılan etkinliktir" (C21-Kabul edilebilir).

VNOS-C anketinin üçüncü sorusu, "Bilimsel bilginin gelişimi deney yapmayı gerektirir mi?", şeklindedir. Sınıf öğretmeni adaylarının, bu soruya yönelik görüşleri kategorilere ayrılmış ve sınıf düzeyine göre yüzdelik dağılımlarına Şekil 5 'te yer verilmiştir:

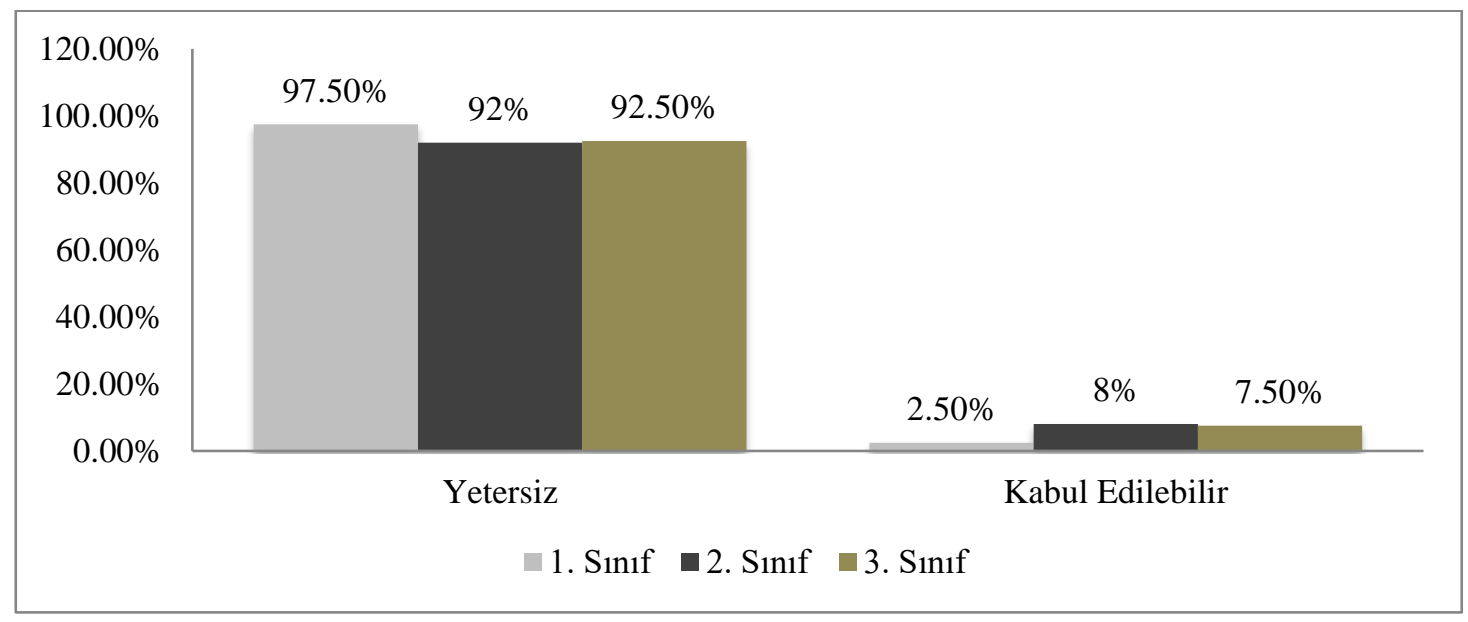

Şekil 5. Öğretmen Adaylarının VNOS-C'nin Üçüncü Sorusuna Verdikleri Cevapların Sınıf Düzeyine Göre Yüzdelik Dağılımları 
Şekil 5 incelendiğinde, öğretmen adaylarının çoğunlukla "yetersiz" düzeyde görüş bildirdikleri görülmüştür. Daha az sayıdaki öğretmen adayları "kabul edilebilir" düzeyde görüşlere sahiptir. "Bilgili" görüşlere sahip öğretmen adayı bulunmamaktadır. 1. sınıf öğretmen adaylarının $(\% 97,5) ' i, 2$. sınıf öğretmen adaylarının (\%92)'si ve 3. sınıf öğretmen adaylarının $(\% 92,5)$ 'i "yetersiz" görüşlere sahiptir. 2. ve 3. sınıf öğretmen adaylarının yetersiz görüş oranları benzerlik göstermektedir. "Kabul edilebilir" görüşlerin oranı, 1. sınıf öğretmen adaylarında $(\% 2,5), 2$. sınıf öğretmen adaylarında $(\% 8)$ ve 3 . sınıf öğretmen adaylarında $(\% 7,5)$ oranında olduğu görülmüştür. 1. sınıf öğretmen adaylarının, diğer sınıflara oranla daha az "kabul edilebilir" düzeyde görüşlere sahip oldukları belirlenmiştir.

\section{"Yetersiz" Kategorisine Ait Görüsşler}

Yetersiz görüşlere sahip öğretmen adayları, bilimsel bilginin gelişimi için deneylerin gerekli olduğunu ifade etmişlerdir. Öğretmen adaylarının cevapları incelendiğinde, deneylerin bir şeyleri ispatlamak ve somutlaştırmak için gerekli olduğu yönünde görüş bildirmişlerdir. Bilimsel iddiaların, gözlem ve çıkarıma dayandırılması gerektiğine dair bir görüş bildiren öğretmen adayı bulunmamaktadır. Bir öğretmen adayın ise, bilimsel bilginin gelişimi için deneylerin gerekli olmadığını belirtmiş ancak doğru bir açıklamada bulunmamıştır.

"Evet gerektirir. Çünkü bilim kanitlanmış bilgiler ister. Kanıtlamak için de deney şarttır" (A1Yetersiz ).

"Deneyler ile bilginin somutlaşması daha kolay olabilir. Örneğin; KCL deneyi ile kütlenin korunumu ilkesini somutlaştırarak görürüz" (B39-Yetersiz).

"Hayır. Bilimsel bilgide kesinlik vardır. Bu yüzden deneye gereksinim duyulmaz" (B13Yetersiz).

3. sınıf öğretmen adaylarından bazıları ise, bilimsel bir bilginin herkes tarafından kabul edilmesi gerektiğine vurgu yaparak, deneylerin hep aynı sonuçları vermesi gerektiğini belirtmiştir.

"Bilimsel bir bilgi herkes tarafindan kabul edilmelidir. Herkesin kabul etmesi için bilginin deneyde hep ayni sonucu vermesi gereklidir" (C6-Yetersiz).

\section{“Kabul Edilebilir” Kategorisine Ait Görüşler}

Kabul edilebilir görüş bildiren öğretmen adaylarının, bilimsel bilginin gelişiminde gözlemlerin önemine değindiği görülmüştür. Bazı öğretmen adayları gözlemler yoluyla çıkarım yapıldığını dolaylı olarak ifade etmiştir.

"Benim cevabım evet. Çünkü her gelişimin aşamalar gözlem yapmayı gerektirir. Bu da deneylerle mümkündür" (B16-Kabul edilebilir).

"Bilimsel bilginin gelişimi bilimsel yöntemler sayesinde olur. Bilimsel yöntem deney ve gözleme dayalıdır. Örneğin; hangi maddenin daha çok basınç uygulayacağını ölçmek için yapılan deneyler gibi... (raptiye, topuklu ayakkabl, kar ayakkabısl)"(C28-Kabul edilebilir).

2. sınıfta öğrenim gören bir öğretmen adayı, bilimsel bilginin gelişimi için her zaman deneylere ihtiyaç duyulmadığını belirtmiştir.

"Hayır gerekmez. Çünkü her bilimsel bilgi deneyle onaylanmiyor ve elde edilmiyor" (B4-Kabul edilebilir). 


\subsection{Bilimin Çıkarıma Dayalı Doğası Alt Boyutuna Yönelik Bulgular}

VNOS-C anketinin dördüncü sorusu, "Bilim adamları atomun yapısı hakkında nasıl bu kadar emindirler? Atomun nasıl bir yapıda olduğunu belirlemek için bilim adamlarının nasıl kanıtlar kullandıklarını düşünüyorsunuz?" şeklindedir. Sınıf öğretmeni adaylarının, bu soruya yönelik görüşleri kategorilere ayrılmış ve sınıf düzeyine göre yüzdelik dağılımlarına Şekil 6'da yer verilmiştir.

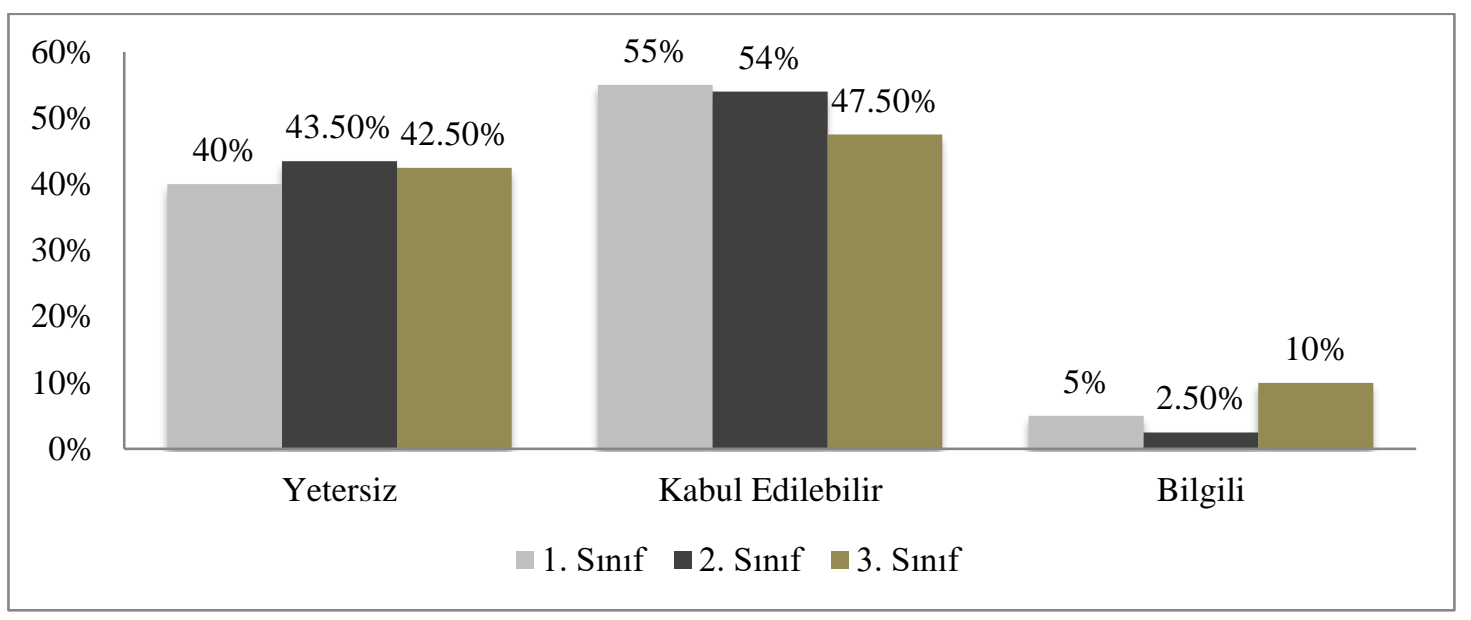

Şekil 6. Öğretmen Adaylarının VNOS-C’nin Dördüncü Sorusuna Verdikleri Cevapların Sınıf Düzeylerine Göre Yüzdelik Dağılımları

Şekil 6 incelendiğinde, öğretmen adaylarının "yetersiz" düzeydeki görüşlerinin oranlarının benzer olduğu görülmektedir. 1. sınıf öğretmen adaylarının (\%40)'ının, 2. sinıf öğretmen adaylarının $(\% 43,5)$ 'inin ve 3. sınıf öğretmen adaylarının $(\% 42,5)$ 'inin yetersiz görüşlere sahip oldukları görülmüştür. Kabul edilebilir görüşlerin sınıf düzeyine göre oranı, 1. sınıflarda (\%55), 2. sinıflarda $(\% 54)$ ve 3. sinıflarda $(\% 47,5)$ 'dir. 1. ve 2. sinıf öğretmen adaylarının "kabul edilebilir" görüş oranlarının birbirine yakın olduğu belirlenmiştir. Bilgili görüşlerin oranının, 1 . sinıflarda $(\% 5)$, 2. sinıflarda $(\% 2,5)$ ve 3. sinıflarda $(\% 10)$ olduğu görülmektedir. 3. sinıf öğretmen adaylarının, 1. ve 2 . sınıf öğretmen adaylarına göre daha fazla bilgili görüşlere sahip oldukları görülmüştür. Öğretmen adaylarının genellikle "kabul edilebilir" ve "yetersiz" düzeyde görüş bildirdikleri ancak çok azının "bilgili” düzeyde görüşlere sahip oldukları belirlenmiştir.

\section{"Yetersiz" Kategorisine Ait Görüşler}

Bilim insanlarının, atomun yapısından nasıl bu kadar emin olduklarına ilişkin görüşler incelendiğinde, her üç sınıf düzeyindeki öğretmen adaylarının, bilim insanlarının atomu mikroskopta çıplak gözle gördüklerine ve bu durumu teknolojik araç gereçler yardımıyla yapabildiklerine ilişkin ifadelere yer vermişlerdir.

"Eski zamanlarda nasıl olduğuna dair fikrim yok. Fakat bu zamanda teknolojinin sağladı̆ğ imkânlarla kanitlar kullanmışlardır” (A24-Yetersiz).

"Çünkü canlı bir atomu mikroskopla incelemişlerdir. Çıplak gözle görülmüştür. Mikroskopla incelenen atom, kanit olarak kişilere gösterilmiştir" (C7-Yetersiz).

Birinci ve ikinci sınıfta öğrenim gören bazı öğretmen adayları, bilim insanlarının atomu parçalayarak bu kadar emin oldukları yönünde görüşlere sahip oldukları belirlenmiş̧tir. 
"Yaptıkları deneyler sonucunda elde ettikleri veriler yüzünden eminlerdir. Atomu parçalayarak kanitlamışlardır" (B28-Yetersiz).

\section{“Kabul Edilebilir” Kategorisine Ait Görüşler}

Kabul edilebilir görüşlere sahip öğretmen adayları, önceden yapılan çalışmaların geliştirilmesi ile gözlem ve deney yoluyla çeşitli benzetmeler yoluyla emin olduklarını ifade etmişlerdir. $\mathrm{Bu}$ öğretmen adaylarının, deney ve gözlemlerin yapıldığına değinmelerine karşın, çıkarımın önemine değinmedikleri görülmektedir.

"Deney ve gözlem yaparak emin olmuşlardır. Yani düşüncelerinin kaynağı vardır ve birikimli olarak ilerlemiştir. Deneylerin bunun için yeterli olduğunu düşünüyorum” (A1-Kabul edilebilir).

"Örneğin; Thomson üzümlü keke benzetmiştir. Yani bu şekilde benzetmeler yaparak kanıtlamaya çalışmışlardır” (B13-Kabul edilebilir).

\section{“Bilgili”" Kategorisine Ait Görüşler}

Bilgili görüşlere sahip öğretmen adayları, bilim adamlarının atomun yapısı hakkındaki bilgilere deneysel çıkarım, benzetme ve modellemeler yaparak ulaştıklarını ifade etmişlerdir.

"Çünkü birçok deney yapmışlardır ve buldukları sonuçlardan yola çıkarak hayata uyarlamışlardır. Mesela üzümlü kek benim kafama en uygun yatan örnek. Keki atom, içindeki üzümü proton olarak görmüşlerdir" (A14-Bilgili).

VNOS-C anketinin yedinci sorusu, "Bilim adamları türün özelliklerinin ne olduğuna dair nasıl emin olabiliyorlar? Bilim adamlarının 'tür nedir?" sorusuna cevap vermek için hangi kanıtlar kullandıklarını düşünüyorsunuz?" şeklindedir. Sınıf öğretmeni adaylarının, bu soruya yönelik görüşleri kategorilere ayrılmış ve sınıf düzeyine göre yüzdelik dağılımlarına Şekil 7'de yer verilmiştir:

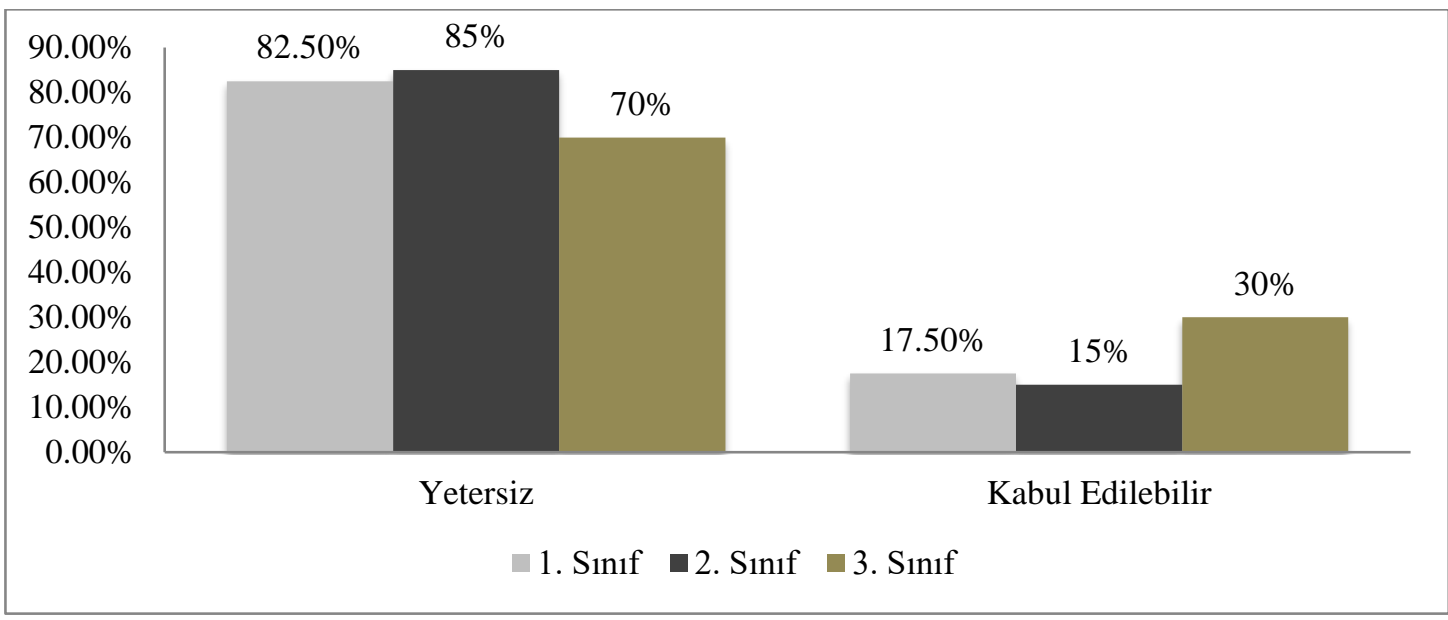

Şekil 7. Öğretmen Adaylarının VNOS-C'nin Yedinci Sorusuna Verdikleri Cevapların Sınıf Düzeyine Göre Yüzdelik Dağılımları

Şekil 7 incelendiğinde, 1. sınıf öğretmen adaylarının $(\% 82,5)$ 'inin, 2. sınıf öğretmen adaylarının (\%85)'inin ve 3. sınıf öğretmen adaylarının (\%70)'inin yetersiz görüşlere sahip oldukları 
Sınıf Öğretmeni Adaylarının Bilimsel Bilginin Epistemolojisine Yönelik İnançlarının İncelenmesi

görülmektedir. 1. ve 2. sınıf öğretmen adaylarının "yetersiz" düzeydeki görüşlerinin oranları benzerlik göstermektedir. 3. sınıf öğretmen adayları, diğer sınıflara oranla daha az "yetersiz" görüşlere sahiptir. "Kabul edilebilir" görüşler, 1. sınıf öğretmen adaylarında $(\% 17,5) ; 2$. sınıf öğretmen adaylarında (\%15) ve 3. sınıf öğretmen adaylarında (\%30) oranında olduğu görülmüştür. 3. sınıf öğretmen adaylarının "kabul edilebilir" düzeydeki görüşlerinin oranı, diğer sınıflara göre daha fazla olduğu görülmüştür. 1., 2. ve 3. sınıflarda bilgili görüşlere sahip öğretmen adayı bulunmamaktadır. Öğretmen adaylarının çoğunlukla "yetersiz" görüşlere sahip oldukları görülmektedir.

\section{"Yetersiz” Kategorisine Ait Görüşler}

Yetersiz görüşlere sahip öğretmen adayları, bilim adamlarının türün özelliklerini belirlerken, canlıların verimli döller sağlayıp sağlamamasına bakarak, doğal ortamlarında gözlemleyerek, canlıların birbiriyle ilişkilerini inceleyerek ve benzerlik ve farklılıklarını ortaya koyarak bu kadar emin olduklarını ifade etmişlerdir. Bu öğretmen adayları, bilim adamlarının "tür nedir?" sorusuna cevap vermek için canlıların protein dizilimi, gen yapısı ve vücut yapılarına bakarak kanıtlar sunduklarını belirtmişledir.

"Belli bir tür için gruplara ayırarak, onların benzer ya da farklı davranışlarını belirleyerek bir sonuca varmış olabilirler. Bu şekilde netlik kazanmıştır” (A15-Yetersiz).

"Tür, aralarında verimli döller oluşturan canlılara deniliyor. Sinıflandırırken homolog organlara, protein benzerliklerine vb. baklliyor" (A21-Yetersiz).

Canlıları yan yana getirerek benzer özellik gösterenleri aynı sınıfa dâhil etmişlerdir." (B1Yetersiz).

"DNA dizilişleri, protein ve enzim yapıları canlılarda farklılık gösterebilir. Canlıların aynı türden olduğuna kanıt olarak; kromozom sayılarının eşit olması, aynı beslenme grubu, ortak atadan gelmeleri ispat edilebilir" (C19-Yetersiz).

\section{“Kabul Edilebilir” Kategorisine Ait Görüşler}

Kabul edilebilir görüşlere sahip öğretmen adayları, bilim adamlarının türün özelliklerinin ne olduğuna dair nasıl bu kadar emin olduklarını,canlılar üzerindeki deney ve gözlemleri sayesinde olduğunu ifade etmişlerdir.

"Bilim adamları deney ve gözlemler sonucu tür kavramını oluşturmuşlardır" (A27- Kabul edilebilir).

"Çeşitli deneyler, gözlemler yaparak türün ne olduğunu kanıtlamaya çalışmışlardır" (B13Kabul edilebilir).

"Bilim adamalı tür üzerinde birçok deney ve gözlem yapmışlardır. Bu sonuçlardan yola çıkarak türün ne olduğunu tanımlamışlardır” (C16- Kabul edilebilir).

\section{Tartışma ve Sonuçlar}

Bilimin kesin olmayan doğası kapsamında, öğretmen adaylarının büyük oranda "kabul edilebilir" bakış açısına sahip oldukları görülmüştür. Öğrenim görülen sınıf düzeyi ilerledikçe, yetersiz görüşlere sahip öğretmen adaylarının sayılarının azaldığı tespit edilmiştir. Sınıf öğretmeni adaylarının, bilimin tanımına ilişkin yetersiz görüşlere sahip olmalarının nedenleri, 
fen bilimlerini din ve felsefe gibi alanlardan ayıran özelliklerin kesin olduğunu, kişiden kişiye değişmediğini, herkes tarafından kabul edildiğini ve sonuçlarının her zaman aynı olduğunu belirten yanlış bilgilere ve eksik öğrenmelere sahip olmaları olabilir. Öğretmen adaylarının bu yanılgılara sahip olmalarının nedeni ise, bilimsel bilginin mutlak doğruluk içerdiği ve hatalardan arınmış olduğu düşüncesi olabilir. İlgili alan yazın incelendiğinde, öğretmen adaylarının bilimsel bilginin değişebileceğine inandıkları ancak bilimsel bilgiye ilişkin yanlış ve eksik bilgilerinden dolayı yeterli görüşlere sahip olmadıkları belirlenmiştir (Arı, 2010; Korkmaz, 2018). Bu çalışmanın sonuçları, ilgili literatürde öğretmenlerin bilimsel bilgilerin değişemez olduğuna ilişkin görüşleri içeren çalışmalar ile benzerlik göstermektedir (Bora, 2005; Craven, Hand \& Prain, 2002; Murcia \& Schibeci, 1999).

Sınıf öğretmeni adaylarının, teori ile bilimsel yasa arasındaki farka ilişkin görüşleri incelendiğinde, benzer yanılgılara sahip oldukları bulunmuştur. Öğretmen adaylarının bilimsel kanun, yasa ve teorilerin hiyerarşik bir yapıda olduğuna ilişkin sahip oldukları kavram yanılgıları, literatürdeki bazı çalışmalarla benzerlik göstermektedir (Ryan \& Aikenhead, 1992; Sarkar, 2010; Shiang-Yao \& Lederman, 2007; Turgut, 2009). Bu çalışmada dikkat çeken diğer bir bulgu ise,öğretmen adaylarının bilimsel kanunları ispatlanmış, herkes tarafından kabul gören, değişmez ve kesin bilgiler olarak görmeleridir. Öğretmen adaylarının kavram yanılgılarına sahip olmalarının sebebi, geçmiş yıllarda lise müfredatında yer alan bilimsel yöntem basamaklarında hipotez, teori ve bilimsel kanunların hiyerarşik bir ilişkide gösterilmesinden dolayı, fen eğitimine karşı pozitivist bir anlayışa sahip olmaları olabilir. Ayrıca öğretmen adaylarının bilimsel bilginin değişemez olduğuna ilişkin yanlış inançlarının bu soruda da devam ettiği belirlenmiştir. İlgili literatür incelendiğinde, öğretmen adaylarının teori ve bilimsel kanuna ilişkin benzer yanılgılara sahip oldukları görülmüştür (Buaraphan, 2010; Turgut, 2009; Ünlü, 2015).

Öğretmen adaylarının, teorilerin zamanla değişip değişmediğine ilişkin görüşleri incelenmiş ve öğrenim görülen sınıf düzeyi ilerledikçe, yetersiz görüşlere sahip öğretmen adaylarının sayılarının azaldığı tespit edilmiştir. Sınıf öğretmeni adaylarının çoğunun, teorilerin değişebileceğini savundukları görülmüştür ancak teorilere ilişkin kavram yanılgılarının bu soruda da devam ettiği belirlenmiştir. Öğretmen adaylarının teorilerin değişip değişmediğine ilişkin yetersiz görüşlere sahip olmalarının nedenleri, teori ve bilimsel kanuna ilişkin kavram yanılgıları ile ortaöğretim ve lise müfredatındaki yanlış bilgileri zihinlerinde yapılandırmaları olabilir (Doğan Bora, 2005; Songer \& Linn, 1991). İlgili alan yazın incelendiğinde, öğretmen adaylarının teorilerin değişebileceğine inanmalarına karşın bilginin kesin olduğu ve kişiden kişiye değişmeyeceğine inandıkları belirlenmiştir (Altındağ, 2010; Craven vd., 2002).

Araştırmanın bilimin deneysel doğasına yönelik sonuçlarına bakıldığında, sınıf öğretmeni adaylarının deneyin tanımına ilişkin büyük oranda "yetersiz" görüşlere sahip oldukları görülmüştür. Nitekim bu sonuç, Özcan'ın (2013) çalışmasındaki, öğretmen adaylarının bilimin deneysel doğasına ilişkin yetersiz görüşlere ve deneyin tanımına ilişkin kavram yanılgılarına sahip oldukları sonuçları ile örtüşmektedir. Ayvacı ve Er Nas (2012) çalışmasında, öğretmen adaylarının bilimin deneysel doğasına ilişkin görüşlerinin uygulama öncesinde, \%91 oranında zayıf düzeyde olduğu sonucuna ulaşmıştır. Çalışmanın sonuçları, öğretmen adaylarının bir şeyin/hipotezin/kanunun doğruluğunu ya da yanlışlığını ispatlamak, soyutu somuta çevirmek ve gerçek bilgiyi bulmak için laboratuvar ortamlarında yapılan bir işlem olarak tanımladıklarını göstermektedir. Bu durum, öğretmen adaylarının deneylerin niçin yapıldığına ilişkin yeterli bilgiye sahip olmadıklarını göstermektedir.

Öğretmen adaylarının, bilimin deneysel doğasına yönelik görüşlerinin, çoğunlukla yetersiz düzeyde olduğu belirlenmiş ve sınıf düzeyleri arasında belirgin farklılıklar görülmemiştir. Literatürde yer alan bazı çalışmalar (Aslan, Yalçın \& Taşar, 2009; Çavuş Güngören, 2015) 
öğretmen adaylarının bilimin deneysel doğasına ilişin yetersiz görüşlere sahip oldukları yönündeki sonuçlarını desteklemektedir. Öğretmen adaylarının çoğunun, deneylerin bilimsel bilgiyi ispat etmek, somutlaştırmak, kesinleştirmek ve pekiştirmek için gerekli olduğu yönünde görüş bildirdikleri belirlenmiştir. Ayrıca öğretmen adaylarının, bilimin gözlemsel ve çıkarımsal boyutlarına değinmedikleri görülmüş ve bilimsel bilginin yalnızca deneyler aracıllı̆ı̆yla olabileceğini belirten yanlış bilgilere sahip oldukları tespit edilmiştir. Benzer olarak, Bayır (2016) fen bilgisi öğretmenleri ile yürüttüğü çalışmasında, öğretmenlerin, deney olmadan bilim olmayacağ1 ve bilimsel bilginin doğruluğunun kanıtlanması için deneylerin gerekli olduğu yönünde yetersiz görüşlere sahip oldukları sonucuna ulaşmıştır. Öğretmen adaylarının yetersiz görüşlere sahip olmalarının nedenleri, bilimsel bilgiye gözlemler aracılığıyla da ulaşılabileceği yönünde eksik bilgilere sahip olmaları ve bilimsel bilginin yalnızca deneyler aracılığıyla olabileceğini düşünmeleri olabilir. Çalışmanın dikkat çekici noktası, öğretmen adaylarının bilimin kesin olmayan doğasına yönelik yanlış bilgilerinin, bilimin deneysel doğasında da devam etmesidir.

Bilimin gözlem ve çıkarıma dayalı doğası kapsamında, öğretmen adaylarının, atomların doğrudan gözlemlendiği, bilim adamlarının atomu parçalayarak sonuçlara ulaştıklarını ifade eden yanlış bilgilere sahip oldukları belirlenmiştir. Bu sonuçlara benzer olarak, Morgil, Temel, Güngör-Seyhan ve Ural-Alşan (2009) ise çalışmasında, öğretmen adaylarının bilimin çıkarıma dayalı doğasına yönelik görüşlerinin \%70 oranında "orta" düzeyde olduğu sonucuna ulaşmıştır. Öğretmen adaylarının görüşlerinin bu yönde olmasının sebebi, bilimde gerçeklik olduğu ve hayallere yer verilemeyeceği düşüncesi olabilir. Ayrıca öğretmen adaylarının atomun yapısı ile ilgili sonuçların gözlem ve deneye dayandırıldığını ifade etmelerine karşın, çıkarımlardan hiç söz etmemişlerdir. Bunun sebebi ise, öğretmen adaylarının gözlem ve çıkarım arasındaki farkı ayırt edememeleri olabilir. Araştırmanın dikkat çekici bir sonucu ise, öğretmen adaylarının bilginin mutlak doğru olmasından yola çıkarak, "kesinlik" algısıyla sürekli olarak "ispat etme" ifadelerini kullandıklarıdır. Yani, bilimin kesin olmayan doğasına ilişkin yanılgıların, bilimin gözlem ve çıkarım alt boyutlarında da devam ettiği görülmektedir. Bu alt boyut kapsamında yer alan, türün tanımına ilişkin bilim insanlarının nasıl kanıtlar kullandıkları sorusuna ilişkin "yetersiz" kategorisindeki görüşlerin diğer kategorilere oranla daha fazla olduğu görülmüştür. Görüsslerin oranları incelendiğinde, birinci ve ikinci sınıf öğretmen adayları arasında belirgin farklılıklar görülmemekle birlikte, üçüncü sınıf öğretmen adaylarının lehine bir farklılık belirlenmiştir. Öğretmen adaylarının bilim insanlarının, teknolojik imkanlara, genetik bilimine bağlı olarak karar verdikleri yönünde yanlış bilgilere sahip oldukları belirlenmiştir. Öğretmen adaylarını bu şekilde düşünmelerinin sebepleri, bilimde deney ve gözlemin olduğunu fark etmelerine rağmen bilimin çıkarımsal boyutunu göz ardı etmeleridir. Benzer şekilde, literatürde, öğretmen ve öğretmen adaylarının bilimin gözlem ve çıkarıma ilişkin boyutuna ilişkin bilgilerinin yetersiz olduğu sonuçlarına ulaşılmıştır (Köseoğlu, Tümay \& Üstün, 2010; Önen, 2011).

Öğretmen adaylarının, bilimsel bilginin doğasına yönelik görüşlerinin incelendiği bu çalışmada, 1., 2. ve 3. sınıfta öğrenim gören sınıf öğretmeni adayları arasında belirgin farklılıklar görülmemiştir. Genel olarak, her sınıf düzeyindeki öğretmen adaylarının, bilimsel bilginin özellikleri ve nasıl oluştuğu hakkında yetersiz bilgilere sahip oldukları belirlenmiştir. Ayrıca her sınıf düzeyindeki görüşlerin de benzer olduğu sonucuna ulaşılmıştır. Sınıflar arasında belirgin farklılıklar olmamasının sebebi, kavram yanılgılarının değişime dirençli olmasıdır. Yani, sınıf düzeyindeki ilerlemenin ya da fen ders saatlerinin artmasının, bu yanılgıları gidermede bir etkisi olmadığı düşünülmektedir. Çünkü kavram yanılgıları, sınıf düzeyine bağlı olmayıp, en yetkin bireylerde bile görülmektedir. Öğretmen adaylarının, fakültelerde verilen derslerle yeterli donanıma sahip oldukları düşüncesi de, yanlış bilgilerin sorgulanmasının önünde bir engeldir. 
Temelde, öğretmen adaylarındaki bu yanılgıların belirlenmesi, ders içeriklerinin onların mevcut durumlarını göz önünde bulundurarak yeniden düzenlenmesi açısından önemlidir.

$\mathrm{Bu}$ çalışmadan elde edilen bulgular doğrultusunda geliştirilen öneriler aşağıda maddeler halinde verilmiştir:

$\checkmark \quad$ Öğrencilere eğitim süreçleri boyunca yapılan yönlendirmeler, bilimin doğası ile ilgili yanlış ve eksik öğrenmelere yol açmaktadır. Bilimin doğası ile ilgili kavramların öğrencilerin zihninde doğru bir şekilde yerleşmesi için öğretimin nasıl gerçekleştirilmesi ve nasıl bir yol izlenmesi gerektiğine yönelik çalışmalar yapılabilir.

$\checkmark \quad$ Farklı branşlara sahip öğretmen adayları ile bilimin doğasına yönelik nicel bir araştırma yürütülerek, branşlar arasındaki benzerlik ya da farklılıklara bakılabilir.

$\checkmark \quad$ Sınıf öğretmeni adaylarının bilimin doğasına ilişkin yeterli düzeyde bilgi sahibi olmaları için program hazırlayıcıların, sınıf öğretmenliği eğitim programlarında "Bilimin Doğası, Bilim Tarihi ve Bilim Felsefesi" gibi derslere yer vererek, düzenlemeler yapması gerektiği düşünülmektedir.

$\checkmark$ Bilimin doğası boyutları ile ilgili en fazla yetersiz görüşlerin, bilimin çıkarıma dayalı doğası ile olduğu görülmüştür. Öğretim üyeleri, öğretmen adaylarına bilimin doğası hakkında çıkarım yapabilecekleri ortamlar yaratmalıdır.

$\checkmark \quad$ Sınıf öğretmeni adaylarına, laboratuvar derslerinde bağımsız ve yaratıcı düşünmeleri, gözlem ve çıkarım yapmaları, araştırmacı kişiliğe sahip olmaları ve deney sonuçlarını yorumlayabilmeleri için açık uçlu deneyler yaptırılarak, rehberli sorgulama ve sorgulama yaklaşımları benimsenebilir.

\section{Kaynaklar}

AAAS. (1989). Science for all Americans. New York: Oxford University Press.

Abd-El-Khalick, F., \& Lederman, N. G. (2000). The influence of history of science courses on students' views of nature of science. Journal of Research in Science Teaching, 37(10), 1057-1095.

Abd-El-Khalick, F. (2001). Embedding nature of science instruction in pre-service elementary science courses: Abandoning scientism, but... Journal of Science Teacher Education, 12(3), 215-233.

Abd-El-Khalick, F., Bell, R. L., \& Lederman, N. G. (1998). The nature of science and instructional practice: Making the unnatural natural. Science Education, 82(4), 417-436.

Akerson, V. L., \& Donnelly, L. A. (2010). Teaching nature of science to K-2 students: What understandings can they attain? International Journal of Science Education, 32(1), 97124.

Altındağ, C. (2010). Bilimin doğasını öğretmen adaylarına öğretmeye yönelik bir çalışma (Yayımlanmamış yüksek lisans tezi). Pamukkale Üniversitesi, Fen Bilimleri Enstitüsü, Pamukkale.

Arı, Ü. (2010). Fen bilgisi ögretmen adaylarının ve sınıf ögretmen adaylarının bilimin doğası hakkındaki görüşlerinin incelenmesi (Yayımlanmamış yüksek lisans tezi). Fırat Üniversitesi, Fen Bilimleri Enstitüsü, Elazı ̆̆.

Aslan, O., Yalçın, N., \& Taşar, M. F. (2009). Fen ve teknoloji öğretmenlerinin bilimin doğası hakkındaki görüssleri. Ahi Evran Üniversitesi Eğitim Fakültesi Dergisi, 10(3), 1-8. 
Ayvacı, H. Ş., \& Er Nas, S. (2012). Yeni yapılandırılmış çoklu birleştirilmiş yöntemle bilimin doğasının unsurlarını öğretmeye yönelik bir pilot çalışma. Uludă̆ Üniversitesi Eğitim Fakültesi Dergisi, 25(1), 103-121.

Bayır, E. (2016). Fen bilimleri öğretmenlerinin bilimin doğasına ilişkin görüşleri: Bilişsel harita örneği. Kastamonu Ĕ̆itim Dergisi, 24(3), 1419-1436.

Bora, G. H. (2005). Argümantasyon temelli fen ögretiminin bilimin doğasına ilişkin görüşler ve epistemolojik inançlar üzerine etkisi (Yayımlanmamış doktora tezi). Pamukkale Üniversitesi, Eğitim Bilimleri Enstitüsü, Pamukkale.

Buaraphan, K. (2010). Pre-service and in-service science teachers' conceptions of the nature of science. Science Educator, 19(2), 35-47.

Büyüköztürk, Ş., Kılıç Çakmak, E., Akgün, Ö. E., Karadeniz, Ş., \& Demirel, F. (2018). Bilimsel araştırma yöntemleri. (24. Bask1). Ankara: Pegem Akademi.

Craven, J. A., Hand, B., \& Prain, V. (2002). Assessing explicit and tacit conceptions of the nature of science among pre-service elementary teachers. International Journal of Science Education, 24(8), 785-802.

Çakıcı, Y. (2009). Fen eğitiminde bir ön koşul: Bilimin doğasını anlama. M.Ü. Atatürk Eğitim Fakültesi Eğitim Bilimleri Dergisi, 29, 57-74.

Çavuş, S. (2010). İlköğretim fen bilgisi ve matematik öğretmenliği lisans ögrencilerinin bilimin doğası hakkındaki görüşlerinin geliştirilmesi (Yayımlanmamış yüksek lisans tezi). Abant İzzet Baysal Üniversitesi, Sosyal Bilimler Enstitüsü, Bolu.

Çavuş Güngören, S. (2015). Fen bilgisi ögrretmen adaylarının farklı ögrretim yöntemleriyle bilimin doğasının öğrenimi ve öğretimi hakkındaki gelişsimleri (Yayımlanmamış doktora tezi). Gazi Üniversitesi, Eğitim Bilimleri Enstitüsü, Ankara.

Doğan Bora, N. (2005). Türkiye genelinde ortaöğretim fen branşı öğretmen ve ögrencilerinin bilimin doğası üzerine görüşlerinin araştırılması (Yayımlanmamış doktora tezi). Gazi Üniversitesi, Eğitim Bilimleri Enstitüsü, Ankara.

Doğan, N., \& Abd-El-Khalick, F. (2008). Turkish grade 10 students' and science teachers' conceptions of nature of science: A national study. Journal of Research in Science Teaching, 45(10), 1083-1112.

Emren, M. (2018). Bilim tarihi destekli işlenen “canlllarda enerji dönüşümleri” ünitesinin, lise ögrencilerinin, bilime ve biyoloji dersine olan tutumlart ve bilimin doğası anlaylşları üzerine etkisinin incelenmesi (Yayımlanmamış yüksek lisans tezi). Marmara Üniversitesi, Eğitim Bilimleri Enstitüsü, İstanbul.

Gall, M. D., Borg, W. R., \& Gall, J. P. (1996). Educational research an introduction (6. Bask1). USA: Longman Publisher.

Hançer, A., Şensoy, Ö., \& Yıldırım, H. (2003). İlköğretimde çağdaş fen bilgisi öğretiminin önemi ve nasıl olması gerektiği üzerine bir değerlendirme. Pamukkale Üniversitesi Eğitim Fakültesi Dergisi, 13(13), 80-88.

Hanuscin, D., Akerson, V., \& Phillipson-Mower, T. (2006). Integratingnature of science instruction into a physical science content course for pre-service elementary teachers: NOS views of teaching assistants. Science Education, 90(5), 912-035.

Kaptan, F., \& Korkmaz, H. (1999). İlköğretimde fen bilgisi öğretimi: İlkögretimde etkili ögretme ve ögrenme ögretmen el kitabl. (Modül 7). Ankara: MEB Projeler Koordinasyon Merkezi Başkanlığ1. 
Kavak, N., Tufan, Y., \& Demirelli, H. (2006). Fen-teknoloji okuryazarlığı ve informal fen eğitimi: Gazetelerin potansiyel rolü. Gazi Eğitim Fakültesi Dergisi, 26(3), 17-28.

Korkmaz, D. (2018). Fen bilgisi ögrretmen adaylarının bilimin doğası hakkındaki görüşlerinin belirlenmesi (Yayımlanmamış yüksek lisans tezi). Erciyes Üniversitesi, Eğitim Bilimleri Enstitüsü, Kayseri.

Köseoğlu, F., Tümay, H., \& Üstün, U. (2010). Bilimin doğası öğretimi mesleki gelişim paketinin geliştirilmesi ve öğretmen adaylarına uygulanması ile ilgili tartışmalar. Ahi Evran Üniversitesi Kırşehir Eğitim Fakültesi Dergisi, 11(4), 129-162.

Küçük, M. (2006). Bilimin doğasını ilköğretim 7. sınıf ögrrencilerine öğretmeye yönelik bir çalışma (Yayımlanmamış doktora tezi). Karadeniz Teknik Üniversitesi, Fen Bilimleri Enstitüsü, Trabzon.

Lederman, N. G., Abd-El-Khalick, F., Bell, R. L., \& Schwartz, R. (2002). Views of nature of science questionnaire: Toward valid and meaningful assessment of learners' conceptions of nature of science. Journal of Research in Science Teaching, 39(6), 497-521.

Lederman, N. G. (1992). Students and teachers conceptions of the nature of science: A review of the research. Journal of Research in Science Teaching, 29(4), 331- 359.

MEB, (2013). Illköğretim kurumları (ilkokullar ve ortaokullar) fen bilimleri dersi (3, 4, 5, 6, 7 ve 8. sinıflar) ögretim programı. Talim ve Terbiye Kurulu Başkanlığı, Ankara.

Meichtry, Y. J. (1999). The nature of science and scientific knowledge: Implications for a preservice elementary methods course. Science \& Education, 8, 273-286.

Morgil, İ., Temel, S., Güngör Seyhan, H., \& Ural Alşan, E. (2009). Proje tabanlı laboratuvar uygulamasının öğretmen adaylarının bilimin doğası konusundaki bilgilerine etkisi. Türk Fen Eğitimi Dergisi, 6(2), 92-109.

Murcia, K., \& Schibeci, R. (1999). Primary student teachers' conceptions of the nature of science. International Journal of ScienceEducation, 21(11), 1123-1140.

Önen, F. (2011). Bilimin doğası konusunda derse entegre edilmiş ve edilmemiş doğrudan yansitıcl yaklaşım etkinliklerinin fen bilgisi ögretmen adaylarının bilimsel bilginin doğası anlayışına etkisi: Atom ve kimyasal bağlar (Yayımlanmamış doktora tezi). Marmara Üniversitesi, Eğitim Bilimleri Enstitüsü, İstanbul.

Özcan, H. (2013). Fen bilgisi öğretmen adaylarının fen içeriği ile ilişsilendirilmiş bilimin doğası konusundaki pedagojik alan bilgilerinin gelişimi (Yayımlanmamış doktora tezi). Gazi Üniversitesi, Eğitim Bilimleri Enstitüsü, Ankara.

Ryan, A. G., \& Aikenhead, G. S. (1992). Students' pre-conceptions about the epistemology of science. Science Education, 76, 559-580.

Sarkar, M. M. A., \& Gomes, J. J. (2010). Science teachers' conceptions of nature of science:The case of Bangladesh. Asia-Pacific Forum on Science Learning and Teaching, 11(1), p.1.

Shiang-Yao, L., \& Lederman, N. G. (2007). Exploring prospective teachers' worldviews and conceptions of nature of science. International Journal of Science Education, 29(10), $1281-1307$.

Songer, N.B., \& Linn, M.C. (1991). How do students' views of science influence knowledge integration? Journal of Research in ScienceTeaching, 28, 761-784.

Soslu, Ö. (2014). Fen eğitiminde bilimin doğasını anlama üzerine bir değerlendirme. Bayburt Üniversitesi Eğitim Fakültesi Dergisi, 9(1), 90-100. 
Tao, P. (2003). Eliciting and developing junior secondary students' understanding of the nature of science through a peer collaboration instruction in science stories. International Journal of Science Education, 25, 147-171.

Turgut, H. (2005). Yapılandırıcı tasarım uygulamasının fen bilgisi ögretmen adaylarının bilimsel okuryazarlık yeterliklerinden, "bilimin doğası" ve "bilim-teknolojitoplum"ilişkisi boyutlarının gelişsimine etkisi (Yayımlanmamış doktora tezi). Yıldız Teknik Üniversitesi, Sosyal Bilimler Enstitüsü, İstanbul.

Turgut, H. (2009). Fen bilgisi öğretmen adaylarının bilimsel bilgi ve yöntem algıları. Türk Ĕ̈itim Bilimleri Dergisi, 7(1), 165-184.

Ural, E. (2016). Comparison of pre-service science and pre-service primary school teachers' nature of scienceviews. International J. Soc. Sci. \& Education, 6(1), 98-108.

Ünlü, Z. B. (2015). Fen bilimleri öğretmen adaylarının mezun olmadan önceki ve mezun olduktan sonraki bilimin doğası ile ilgili görüşlerinin incelenmesi (Yayımlanmamış yüksek lisans tezi). Pamukkale Üniversitesi, Eğitim Bilimleri Enstitüsü, Pamukkale.

Yıldırım, C. (2014). Bilim felsefesi. (18. Baskı). İstanbul: Remzi Kitabevi.

Yıldırım, A., \& Şimşek, H. (2008). Sosyal bilimlerde nitel araştırma yöntemleri. Ankara: Seçkin Yayıncılık.

\section{EXTENDED ABSTRACT}

\section{Introduction}

According to the positivist approach, scientists produce science depending on the scientific process and principles determined by scientists. In this context, human crated science is not entirely objective since science has not been discovered but created by scientists.In the researches, it is seen that students and teachers have the opinion that scientists have objectively revealed certain facts by using scientific methods in the scientific process. Pre-service teachers need to recognize their scientific knowledge before developing their students' understanding of the nature of science. Teachers' teaching methods and views about the nature of science affect students' learning.

According to teachers with a positivist approach, science is perceived as "objective, universal, based on observation and experiment, revealing certain facts, having a unique scientific method to prove events, independent of prejudice. According to the contemporaryapproach, science:

$\checkmark \quad$ It is a human effort used to understand the physical world.

$\checkmark$ Science always produces imprecise knowledge.

$\checkmark$ Scientists use various methods in scientific research. There is no single universally accepted specific process for doing science. These scientific methods do not follow a set of rules.

$\checkmark \quad$ Science is not entirely based on observation and experiment. Inferences are also crucial in science.

$\checkmark$ Scientific theories are as critical as laws. There is no hierarchical structure between theories and laws.

$\checkmark \quad$ A theory does not have to be supported by evidence to be scientific.

It is crucial to understand the dynamic structure of science and to understand scientific knowledge is not absolute and can change for developing research and inquiry skills. Being skeptical and examining the evidence supporting knowledge are features that need to be 
developed in order to become a scientifically literate individual.Understanding the importance of experiments and observations while creating scientific knowledge is vital for understanding the scientific method. For individuals to learn scientific knowledge, it is necessary to have the correct schemes in their minds about scientific knowledge's properties and how scientific knowledge is obtained.

Students who started taking science classes in elementary school starting from the 3rd grade are officially acquainted with scientific knowledge for the first time. In this context, primary school teachers have a significant role in introducing science and creating correct schemes in students' minds about science and scientific knowledge. The pre-service teachers' opinions about what scientific knowledge is, how it is formed will affect the teaching methods they use and their view of science classes. For this reason, examining the views of pre-service primary school teachers about the subject will contribute to determining their approaches in science classes in their class, exploring the development of their knowledge about the issue during their undergraduate program, and discussing possible solution suggestions.

\section{Method}

In this study, one of the qualitative research methods, the case study design, which is considered appropriate to the nature of the research, was used.In this study, since it was aimed to evaluate the primary school teacher candidates' views on the nature of scientific knowledge based on their current beliefs and to search the details of their misconceptions about the subject, the case study design was preferred.The sample group of the study consisted of a total of 119 classroom teacher candidates studying in the 1st, 2 nd and 3 rd grades at a government university in the 2017-2018 academic year. The study group within the scope of the study was determined by using "convenience sampling", one of the non-random sampling methods. The selected questions in VNOS-C questionnaire were posed to the 1st, 2nd, and 3rd-year primary school teacher candidates and requested to answer the questions. The participants wrote down their answers. In this study, the data obtained from the VNOS-C questionnaire were categorized according to three criteria used: "naive," "has merit," and "informed." The teacher candidates' answers that were not suitable for the nature of science were described as "naive," the reasonable answers that reflect the nature of science but cannot fully explain it as "has merit" and the adequate explanations they reinforce with examples about the nature of science are described as "informed." The researchers gave numbers to the data collected from the participants as A1 to A40 for the freshman teacher candidates, B1 to B39 for the 2nd year teacher candidates, and C1 to $\mathrm{C} 40$ for the 3 rd year teacher candidates.

\section{Findings, Discussion and Conclusion}

When the percentages of the primary school teacher candidates' views on the definition of science were examined, it was seen that most of them have views in the "has merit" category. It was determined that the primary school teacher candidates had misinformation and incomplete learning, stating that the features that distinguish science from fields such as religion and philosophy were certain, did not vary from person to person, everyone accepted them and their results were always the same.

It was determined that most of the primary school teacher candidates had views in the "naive" category" on the difference between theory and scientific law. It was determined that the preservice teachers had misconceptions about the hierarchical structure of scientific laws and theories. The teacher candidates had misconceptions since they had a positivist approach to science because of the scientific method's misstatement in the high school curriculum in the past 
years. It was stated that there was a hierarchical relationship between hypotheses, theories, and scientific laws while following scientific method steps.

The views of the teacher candidates on whether the theories have changed over time were examined, and it was determined that most of their views were in "naive" and "has merit" categories. The reasons for teacher candidates' naive views on whether theories have changed over time maybe their misconceptions about theory and scientific law, and they constructed the wrong information in the secondary and high school curricula in their minds (Doğan Bora, 2005; Songer \& Linn, 1991).

Considering the results of the research regarding the empirical nature of science, it was seen that the teacher candidates had mostly "naive" views about the definition of the experiment. The study's findings displayed that the teacher candidates defined the experiments as a process performed in the laboratory to prove the correctness or wrongness of something/hypothesis/law, turn the abstract into the concrete, and find real information. To the question "Does the development of scientific knowledge require experimentation?" which was within the scope of science's empirical nature, the majority of the pre-service teachers answered as "required." It was determined that most of the teacher candidates stated that experiments were necessary to prove, concretize, confirm, and consolidate scientific knowledge. In addition, it was seen that the teacher candidates did not mention the observational and inferential dimensions of science, and they had false information stating that the scientists could obtain scientific knowledge only through experiments. The teacher candidates' naive views may be due to their incomplete information that scientific knowledge can only be obtained through observations and experiments.

When the answers were given to the question of "how scientists are so confident about the structure of the atom?", which was within the scope of the inferential nature of science, it was determined that the majority of the teacher candidates expressed views in "has merit" category, while the substantial part of it was in "naive" category. The teacher candidates generally stated that while determining the atom structure, scientists used technological tools, observed the atom directly by using the microscope, and reached these results by splitting the atom. The reason for those views maybe the thought that there were precision and reality in science and that there was no need for imagination. It was observed that the majority of the views in the "naive" category regarding the question of how scientists use evidence regarding the definition of the species. When the findings were examined, the teacher candidates stated the scientists decided the species' characteristics according to fertility, technological facilities, genetics and the findings of the previous studies. Teacher candidates thought in this way that they ignored the inferential nature of science even though they realized that there were experimentation and observation in science.

\section{Etik Kurul İzin:}

Yapılan bu çalışmada "Yükseköğretim Kurumları Bilimsel Araştırma ve Yayın Etiği Yönergesi”" kapsamında uyulması belirtilen tüm kurallara uyulmuştur. Bu çalışma için etik kurul izni Kahramanmaraş Sütçü İmam Üniversitesi Fen Bilimleri Araştırmaları Etik Kurulu'nun 17.04.2018 tarihli ve 2018/08 sayılı toplantıda alınan kararı ile alınmıştır. 